OPEN ACCESS

Edited by:

Xue Qun Chen,

Zhejiang University, China

Reviewed by:

Liu Chuanyong,

Shandong University, China

Xiao Yu,

Shandong University, China

*Correspondence:

Xueyin Shi

shixueyin1128@163.com

Weifang Rong

weifangrong@shsmu.edu.cn;

weifangrong@hotmail.com

Specialty section: This article was submitted to

Neuroendocrine Science,

a section of the journal

Frontiers in Neuroscience

Received: 09 May 2019 Accepted: 02 December 2019 Published: 17 December 2019

Citation:

Ding $X$, Gao T, Gao P, Meng $Y$, Zheng Y, Dong L, Luo P, Zhang G, Shi $X$ and Rong W (2019) Activation of the $G$ Protein-Coupled Estrogen

Receptor Elicits Store Calcium Release and Phosphorylation of the Mu-Opioid Receptors in the Human

Neuroblastoma SH-SY5Y Cells.

Front. Neurosci. 13:1351.

doi: 10.3389/fnins.2019.01351

\section{Activation of the G Protein-Coupled Estrogen Receptor Elicits Store Calcium Release and Phosphorylation of the Mu-Opioid Receptors in the Human Neuroblastoma SH-SY5Y Cells}

\author{
Xiaowei Ding1,2, Ting Gao², Po Gao², Youqiang Meng ${ }^{3}$, Yi Zheng ${ }^{1}$, Li Dong², Ping Luo², \\ Guohua Zhang ${ }^{2}$, Xueyin Shi ${ }^{1 *}$ and Weifang Rong ${ }^{1,2 *}$ \\ 'Department of Anesthesiology, Xin Hua Hospital, School of Medicine, Shanghai Jiao Tong University, Shanghai, China, \\ ${ }^{2}$ Department of Anatomy and Physiology, Faculty of Basic Medical Sciences, School of Medicine, Shanghai Jiao Tong \\ University, Shanghai, China, ${ }^{3}$ Department of Neurosurgery, Xin Hua Hospital Chongming Branch, School of Medicine, \\ Shanghai Jiao Tong University, Shanghai, China
}

Estrogens exert extensive influences on the nervous system besides their well-known roles in regulation of reproduction and metabolism. Estrogens act via the nuclear receptor $E R \alpha$ and $E R \beta$ to regulate gene transcription (classical genomic effects). In addition, estrogens are also known to cause rapid non-genomic effects on neuronal functions including inducing fast changes in cytosolic calcium level and rapidly desensitizing the $\mu$ type opioid receptor (MOR). The receptors responsible for the rapid actions of estrogens remain uncertain, but recent evidence points to the $G$ proteincoupled estrogen receptor (GPER), which has been shown to be expressed widely in the nervous system. In the current study, we test the hypothesis that activation of GPER may mediate rapid calcium signaling, which may promote phosphorylation of MOR through the calcium-dependent protein kinases in neuronal cells. By qPCR and immunocytochemistry, we found that the human neuroblastoma SH-SY5Y cells endogenously express GPER and MOR. Activation of GPER by $17 \beta$-estradiol (E2) and G-1 (GPER selective agonist) evoked a rapid calcium rise in a concentrationdependent manner, which was due to store release rather than calcium entry. The GPER antagonist G15, the PLC inhibitor U73122 and the IP3 receptor inhibitor 2-APB each virtually abolished the calcium responses to E2 or G-1. Activation of GPER stimulated translocation of PKC isoforms $(\alpha$ and $\varepsilon$ ) to the plasma membrane, which led to MOR phosphorylation. Additionally, E2 and G-1 stimulated c-Fos expression in SH-SY5Y cells in a PLC/IP3-dependent manner. In conclusion, the present study has revealed a novel GPER-mediated estrogenic signaling in neuroblastoma cells in which activation of GPER 
is followed by rapid calcium mobilization, PKC activation and MOR phosphorylation. GPER-mediated rapid calcium signal may also be transmitted to the nucleus to impact on gene transcription. Such signaling cascade may play important roles in the regulation of opioid signaling in the brain.

Keywords: estrogens, G protein-coupled estrogen receptor, calcium mobilization, $\mu$ opioid receptor, protein kinase $\mathrm{C}$, protein phosphorylation

\section{INTRODUCTION}

Estrogens exert an extraordinarily wide spectrum of actions in the human body. Besides the well-known roles in regulation of reproduction and metabolism, estrogens also exert multifaceted influences on neuronal development and neuronal functions (Jensen and Desombre, 1973). Traditionally, estrogens are known to act by interacting with two nuclear receptors, ER $\alpha$ and $\mathrm{ER} \beta$, which function as ligand-activated transcription factors to regulate gene transcription (Jensen and Desombre, 1973; Kuiper et al., 1996; Mosselman et al., 1996; Paech et al., 1997). In addition to this slow genomic mode of actions which typically develop with latencies ranging from an hour to several days, estrogens also directly alter neuronal electrical activity in various brain regions within seconds to minutes, which may underlie the fast effects of estrogens on brain functions such as female reproductive behavior, memory and cognition, neuroprotection and pain (Woolley, 1999; Kelly and Ronnekleiv, 2009; Ogawa et al., 2018).

Although the existence of the non-genomic estrogenic actions is now widely accepted, the mechanisms (the receptors and the signaling cascades) that mediate such effects remain uncertain and much debated. A number of candidate receptors have been proposed, including the classical $\mathrm{ER} \alpha$ that may alternatively be bound to the plasma membrane, several $E R \alpha$ variants (ER $\alpha-52$, $\mathrm{ER} \alpha-46$, and ER $\alpha-36$ ), membrane-associated ER-X, the $\mathrm{G} \alpha_{\mathrm{q}^{-}}$ coupled mERs and more recently the $G$ protein-coupled estrogen receptor (GPER, also known as GPR30) (Rainville et al., 2015).

$G$ protein-coupled estrogen receptor reportedly is enriched in discrete regions of the nervous system, including the hypothalamus, the hippocampus, the cerebral cortex, the dorsal horn of spinal cord and the primary afferent neurons, therefore is ideally positioned to mediate the rapid non-genomic estrogenic actions on reproductive behavior, memory and cognition and pain (Shughrue et al., 1997, 2000; Brailoiu et al., 2007; Kuhn et al., 2008; Dun et al., 2009; Hazell et al., 2009; Takanami et al., 2010; Lu et al., 2013). Indeed, numerous recent studies underscore the role of GPER in mediating the rapid estrogenic effects in the nervous system. For examples, intracerebroventricular infusion of the GPER agonist G-1 rapidly facilitates the female sexual behavior in estradiol-primed rats (Long et al., 2014, 2017). Activation of GPER in the dorsal hippocampus enhances social and object recognition and memory in the rat within $40 \mathrm{~min}$ (Paletta et al., 2018). In spinal cord slice in vitro, G-1 directly depolarizes superficial dorsal horn neurons; in vivo, intrathecal application of G-1 results in pain-related behaviors characterized by caudally directed scratching, biting and licking (Deliu et al., 2012).
Concerning the signaling cascades of the non-genomic effects, it occurs that estrogens may mediate rapid calcium signaling in neuronal and non-neuronal cells by modulating $\mathrm{Ca}^{2+}$ influx or inducing store $\mathrm{Ca}^{2+}$ release (Picotto et al., 1999; Rubio-Gayosso et al., 2000; Huang and Jan, 2001; Chen et al., 2002; Kuo et al., 2010; Petrovic et al., 2011). Thus, $17 \beta$-estradiol (E2) induces rapid $\mathrm{Ca}^{2+}$ influx in hippocampal neurons through activation of L-type $\mathrm{Ca}^{2+}$ channels, which probably mediates estrogen-induced neuroprotection (Wu et al., 2005, 2011; Zhao et al., 2005). E2 was also found to induce rapid $\mathrm{Ca}^{2+}$ release from intracellular $\mathrm{Ca}^{2+}$ stores in hypothalamic astrocytes and in embryonic midbrain dopaminergic neurons (Beyer and Raab, 1998; Kuo et al., 2010). In most cases, the receptor(s) responsible for the rapid $\mathrm{Ca}^{2+}$ rise was not clear, but recent evidence indicate that GPER may mediate estrogen-induced $\mathrm{Ca}^{2+}$ signaling. Revankar et al. (2005) expressed GPER as a fusion protein with green fluorescent protein (GFP) in COS7 cell (monkey kidney fibroblast) and found that activation of GPER resulted in intracellular $\mathrm{Ca}^{2+}$ mobilization and synthesis of phosphatidylinositol 3,4,5trisphosphate in the nucleus. Incidentally, GPER is enriched in the hypothalamic-pituitary axis and the hippocampal formation (Paletta et al., 2018), where E2 has been reported to elicit cytosolic $\mathrm{Ca}^{2+}$ changes. Nevertheless, whether GPER mediates rapid $\mathrm{Ca}^{2+}$ signaling in neuronal cells is still uncertain.

Intracellular $\mathrm{Ca}^{2+}$ as a second messenger may activate protein kinases such as PKC and PKA to phosphorylate downstream effector proteins, which plays fundamental roles in neuronal signaling. Interestingly, E2 was found to rapidly attenuate the ability of mu-opioids to hyperpolarize hypothalamic neurons by uncoupling the $\mu$-opioid receptors (MOR) from activating $G$ protein-regulated inward rectifying potassium (GIRK) channels (Lagrange et al., 1997). Similarly, E2 uncouples other Gi/o-GPCRs, sepcifically $\mathrm{GABA}_{\mathrm{B}}$ and opioid receptorlike (ORL)-1, from activating GIRK channels and the effect was dependent upon activation of PLC, PKA, and PKC (Conde et al., 2016). Therefore, estrogens appear to mediate a $\mathrm{Ca}^{2+}$ dependent phosphorylation and desensitization of Gi/o-coupled GPCRs through activating PKC and PKA. Whether GPER can initiate such non-genomic estrogenic signaling cascades remains to be determined.

The current study aims to test the hypothesis that GPER may mediate rapid $\mathrm{Ca}^{2+}$ signaling and subsequent $\mathrm{Ca}^{2+}$ dependent phosphorylation of MOR through activation of PKC in the human neuroblastoma SH-SY5Y cell line. Indeed, we found that SH-SY5Y cells endogenously express GPER and 
MOR and activation of GPER rapidly stimulates PLC/IP3dependent store $\mathrm{Ca}^{2+}$ release with subsequent $\mathrm{PKC}$ activation and MOR phosphorylation.

\section{MATERIALS AND METHODS}

\section{Chemicals}

G protein-coupled estrogen receptor agonist G-1 and GPER antagonist G-15 were purchased from Cayman Chemical Company (Ann Arbor, MI, United States). The pan-PKC inhibitor Ro 31-8820 was bought from ApexBio Technology Company (Houston, TX, United States). 17 $\beta$-estradiol (E2) and other reagents were purchased from Sigma-Aldrich (St. Louis, MO, United States) unless otherwise mentioned.

\section{Cell Culture}

The human neuroblastoma cell line, SH-SY5Y, was purchased from the Cell Repository of Chinese Academy of Sciences (Shanghai, China). The murine neuroblastoma Neuro-2a (N2A) cells (a wild type line and N2A cells stably expressing human influenza virus HA, YPYDVPDYA, epitope-tagged MOR) were provided by Dr. Yu Qiu (Shanghai Jiao Tong University School of Medicine). Cells were cultured in Dulbecco Modified Eagle Medium (DMEM), supplemented with 10\% (v/v) fetal bovine serum (FBS), 100 units/ml penicillin, $100 \mu \mathrm{g} / \mathrm{ml}$ streptomycin, $0.11 \mathrm{~g} / \mathrm{L}$ sodium pyruvate and $2 \mathrm{mM}$ glutamine. $250 \mu \mathrm{g} / \mathrm{ml} \mathrm{G} 418$ was added into the medium for Neuro-2a cell line stably expressing human MOR (N2AMT). Cells were incubated at $37^{\circ} \mathrm{C}$ in a humidified atmosphere containing $5 \% \mathrm{CO}_{2}$.

\section{Western Blot Analysis}

Cells cultured to $80 \%$ confluence were collected and placed in RIPA buffer containing protease inhibitors and phosphatase inhibitors to extract total proteins. Protein concentration was determined by BCA assay (Pierce, Rackford, IL, United States). We used the Biotin-Avidin-System to extract plasma membrane proteins. Briefly, SH-SY5Y cells were washed in phosphatebuffered saline (PBS) and subsequently incubated with SulfoNHS-LC-biotin $(250 \mu \mathrm{g} / \mathrm{ml}$ in PBS) for $30 \mathrm{~min}$ and then with $10 \mathrm{mM}$ glycine counteracted superfluous biotin for $20 \mathrm{~min}$ at $4^{\circ} \mathrm{C}$. After extraction of total protein, NeutrAvidin Agarose Beads (Thermo Scientific, CN, United States) were added to the whole-cell lysates and incubated on rotating mixer for $3 \mathrm{~h}$ at $4^{\circ} \mathrm{C}$. The mixture was centrifuged at $10,000 \mathrm{~g}$ for $30 \mathrm{~min}$ at $4^{\circ} \mathrm{C}$. Subsequently, the beads were washed for five times and the plasma membrane proteins were eluted and denatured by $2 \times$ SDS-PAGE sample loading buffer at $100^{\circ} \mathrm{C}$ for $5 \mathrm{~min}$. $25 \mu \mathrm{g}$ of total proteins or $30 \mu \mathrm{l}$ sample loading buffer containing plasma membrane proteins were electrophoresed on $4-8 \%$ Tris-glycine ready gels (Biorad, Hercules, CA, United States). The separated proteins were transferred from the gel to the surface of nitrocellulose membranes (Bio-rad). The membranes were blocked with 5\% fat-free dry milk or 5\% BSA (for detection of phosphorylated MOR, PKC $\alpha, \mathrm{Na}^{+}-\mathrm{K}^{+}$-ATPase) in Tris-buffered saline (TBS) containing $0.1 \%$ Tween-20 for $2 \mathrm{~h}$. Subsequently, the membranes were incubated with primary antibodies for $18 \mathrm{~h}$ at $4^{\circ} \mathrm{C}$ : rabbit GPER (1:1000, Abcam, Cat\# ab39742, RRID:AB_1141090), rabbit anti-pMOR (1:1000, Cell Signaling Technology, Cat\# 3451, RRID:AB_331619), rabbit anti-MOR (1:500, Novus, Cat\# NBP1-31180, RRID:AB_2251717), rabbit anti-PKC $\alpha$ (1:1000, Cell Signaling Technology, Cat\# 2056, RRID:AB_2284227), mouse anti-PKCE (1:1000, BD Biosciences, Cat\# 610085, RRID:AB_397492), rabbit anti-Na ${ }^{+}-\mathrm{K}^{+}$-ATPase (1:3000, Abcam, Cat\# ab76020, RRID:AB_1310695) and mouse anti- $\beta$-actin (1:2000, Bioworld Technology, BS6007M). Bound primary antibodies were detected with HRP-conjugated anti-rabbit (1:3000, Bio-Rad, Cat\# 170-6515, RRID:AB_11125142) or antimouse (1:3000, Bio-Rad, Cat\# 170-6516, RRID:AB_11125547) secondary antibody. Immunoreactive bands were visualized using enhanced chemiluminescence (Thermo, Indianapolis, IN, United States), and digital imaging was captured with an Image Quant LAS 4000 mini (GE Healthcare, Life Science). The density of specific bands was analyzed using NIH ImageJ software and was normalized against the loading controls ( $\beta$-actin, GAPDH or $\mathrm{Na}^{+}-\mathrm{K}^{+}$-ATPase).

\section{Immunofluorescence Staining}

SH-SY5Y cells were seeded on glass coverslips and cultured for $24 \mathrm{~h}$ and fixed with $4 \%$ paraformaldehyde for $15 \mathrm{~min}$. After washing with PBS, the cells were first incubated with $50 \mathrm{mM}$ PBS containing 10\% normal goat serum and $0.5 \%$ TritonX-100 at room temperature for $2 \mathrm{~h}$ to block non-specific binding and this was followed by incubation with rabbit anti-GPER (1:500, Abcam, Cat\# ab39742, RRID:AB_1141090) or rabbit anti-MOR (1:500, Novus, Cat\# NBP1-31180, RRID:AB_2251717) at $4^{\circ} \mathrm{C}$ overnight. The cells were rinsed with PBS for four times and were then incubated with goat anti-rabbit Alexa fluor 568 (1:1000; Molecular Probes-Invitrogen, Cat\# A-11077, RRID:AB_141874) or 488 (1:1000; Molecular Probes-Invitrogen, Cat\# R37116, RRID:AB_2556544) secondary antibody at room temperature for $1.5 \mathrm{~h}$. GPER or MOR were counter-stained with a nuclear marker DAPI (1: 1000, Thermo Fisher Scientific, Cat\# PA562248, RRID:AB_2645277) at room temperature for $10 \mathrm{~min}$. The coverslips were mounted on glass slides and the cells were viewed under the fluorescent microscope (Leica DM2500, Leica Microsystems Limited).

\section{Real-Time Reverse Transcription-Polymerase Chain Reaction (RT-PCR)}

Total RNA of SH-SY5Y and Neuro-2a cells was extracted with Trizol (Invitrogen, Shanghai, China) according to the manufacturer's instructions and reversely transcribed into cDNA using oligo-dT primers. Real-time quantitative PCR was then performed using SYBR Green (Qiagen, Shanghai, China) as the reporter dye. All cDNA samples were analyzed in duplicate. The relative level of target mRNA was calculated by the method of $2^{-\Delta \Delta} \mathrm{Ct}$ with GAPDH as the loading control. The primer sets for real-time PCR are as follows: 
GPER (human): Forward 5'-TCACGGGCCACATTG TCAACCTC- $3^{\prime}$ and Reverse $5^{\prime}$-GCTGAACCTCACATC CGACTGCTC-3';

GAPDH (human): Forward 5'-GGAGCGAGATCCC TCCAAAAT- $3^{\prime}$ and Reverse $5^{\prime}$-GGCTGTTGTCATACTTC TCATGG-3';

GPER (mouse): Forward 5'-CCTCTGCTACTCCCT CATCG- $3^{\prime}$ and Reverse 5'-ACTATGTGGCCTGTC AAGGG-3';

GAPDH (mouse): Forward 5'-TGTCTTCACCACCAT GGAGA-3' and Reverse 5'-CGGCCATCACGCCAC AGCTT-3'.

\section{Calcium Imaging}

Cells were incubated with $1 \mu \mathrm{M}$ Fluo-4-AM (Molecular Probes-Invitrogen) and $0.01 \%$ pluronic (Sigma-Aldrich) in the extracellular solution ( $\mathrm{NaCl} 136 \mathrm{mM}, \mathrm{KCl} 5.4 \mathrm{mM}, \mathrm{MgCl}_{2} 1 \mathrm{mM}$, $\mathrm{CaCl}_{2} 1.8 \mathrm{mM}$, HEPES $10 \mathrm{mM}$, Glucose $10 \mathrm{mM}$, and $\mathrm{NaH}_{2} \mathrm{PO}_{4}$ $0.33 \mathrm{mM}$, pH7.4, osmotic pressure $300 \mathrm{mOsm} / \mathrm{L}, \mathrm{MgCl}_{2}$ replaced $\mathrm{CaCl}_{2}$ for calcium free solution) at $25^{\circ} \mathrm{C}$ for $1 \mathrm{~h}$. The cells were continuously superfused with the extracellular solution and imaged using an inverted microscope (Leca DMI4000B). Drugs (or vehicle control) were applied through a micro-perfusion tube positioned to the vicinity of the cells in the field of view. Fluorescent signal was excited at $510 \mathrm{~nm}$ and acquired at $580 \mathrm{~nm}$, and taken every $3 \mathrm{~s}$ through a CCD camera. The signal was monitored online and analyzed offline, using Leica AF6000 software (Leica). The fluorescent traces were calculated as:

$$
\% \text { change in fluorescence }=\frac{\mathrm{F}-\mathrm{F} 0}{\mathrm{~F} 0} \times 100
$$

(F0: the baseline fluorescence of cells before treatments, F: the fluorescence of cells with drugs treatments).

\section{Statistical Analysis}

Data are expressed as mean \pm SEM. Statistical analysis was performed using GraphPad Prism 6 (GraphPad Software Inc., United States). Differences between two groups were analyzed by unpaired or paired $t$-test (two-tailed). Multiple comparisons were made by one-way analysis of variance (ANOVA) with Tukey's post hoc testing. Differences were considered statistically significant when a $P$ value was less than 0.05 .

\section{RESULTS}

\section{SH-SY5Y Cells Endogenously Express GPER and MOR}

$\mathrm{G}$ protein-coupled estrogen receptor mRNA expression in $\mathrm{SH}$ SY5Y, wild type N2A and N2A cell line stably expressing human MOR (N2AMT) was analyzed through RT-PCR. GPER mRNA appeared to be more abundant in SH-SY5Y cells than in N2A and N2AMT cells (Figure 1A). Immunofluorescent staining confirmed SH-SY5Y cells endogenously express GPER and MOR (Figure 1B). GPER immunostaining was located at peri-nuclear sites. Western blot analysis detected GPER in total but not in cytoplasmic membrane protein samples (Figure 1C). Therefore, the endogenously expressed GPER in SH-SY5Y cells was located on certain peri-nuclear organelles, but not on the cytoplasmic membrane.

\section{GPER Mediates Rapid Intracellular Calcium Rise in SH-SY5Y Cells}

To test the hypothesis that activation of GPER mediates rapid $\mathrm{Ca}^{2+}$ signaling, SH-SY5Y and the Neuro-2a cells were exposed to either $17 \beta$-estradiol (E2) or G-1, the latter being a GPER selective agonist that does not bind $\operatorname{ER} \alpha$ or $\operatorname{ER} \beta$ (Bologa et al., 2006). Brief exposure (30 s) of SH-SY5Y cells to increasing concentration of E2 or G-1 (0.01-10 $\mu \mathrm{M})$ both produced fast and concentration-dependent increases in cytosolic $\mathrm{Ca}^{2+}$ levels (Figures 1D-F). Acetylcholine (ACh) was a positive control. Consistent with the intracellular localization of GPER in this cell line, the cell impermeable BSA-conjugated E2 (E2-BSA, $1 \mu \mathrm{M}$ ) was not effective (Figure 1J). In addition, the GPER selective antagonist G15 (Dennis et al., 2009) (3 $\mu \mathrm{M}$ ) almost completely blocked the $\mathrm{Ca}^{2+}$ responses to E2 and G-1 (G15 + E2: $24.43 \pm 3.10 \%$ vs. $\mathrm{E} 2: 207.0 \pm 20.70 \%, P<0.001, n=78$ cells; G15 + G-1: $18.59 \pm 2.79 \%$ vs. G-1: $201.0 \pm 19.74 \%, P<0.001$, $n=56$ cells, Figures $\mathbf{1 G}-\mathbf{I})$. In contrast to the SH-SY5Y cells, Neuro-2a cells did not respond to E2 or G-1 (1 $\mu \mathrm{M})$ with a Ca ${ }^{2+}$ rise, consistent with the low GPER mRNA expression in this cell line (Figure 1K). It was noticed that Neuro-2a cells responded to ATP $(100 \mu \mathrm{M})$ with a rapid $\mathrm{Ca}^{2+}$ rise but not to ACh. These results support the hypothesis that activation of GPER by E2 may mediate rapid $\mathrm{Ca}^{2+}$ signaling in neuroblastoma cells.

\section{GPER-Mediated Calcium Rise in SH-SY5Y Cells Is Due to Store Calcium Release}

We next investigated whether GPER-mediated $\mathrm{Ca}^{2+}$ rise is due to $\mathrm{Ca}^{2+}$ influx or store $\mathrm{Ca}^{2+}$ release. In the $\mathrm{Ca}^{2+}$-free extracellular solution, E2 $(1 \mu \mathrm{M})$ and $\mathrm{G}-1(1 \mu \mathrm{M})$ both still elicited rapid increases in cytosolic $\mathrm{Ca}^{2+}$ with similar magnitudes as seen in the regular $\mathrm{Ca}^{2+}$-containing solution (Figures $2 \mathrm{~A}-\mathrm{C}$ ) (E2 $\mathrm{Ca}^{2+}$-free: $154.1 \pm 11.77 \%, n=55$ cells vs. E2 $\mathrm{Ca}^{2+}$ containing: $174.5 \pm 20.09 \%, n=60$ cells, $P>0.05$; G-1 Ca ${ }^{2+}$ free: $149.8 \pm 8.40 \%, n=55$ cells vs. G-1 Ca ${ }^{2+}$-containing: $176.5 \pm 14.34 \%, n=62$ cells, $P>0.05$, Figure $2 G$ ), suggesting that the GPER agonists evoked store $\mathrm{Ca}^{2+}$ release rather than $\mathrm{Ca}^{2+}$ influx. In support, the broad-spectrum voltage-dependent $\mathrm{Ca}^{2+}$ channel blocker $\mathrm{CdCl}_{2}(200 \mu \mathrm{M})$ failed to block the increase in $\left[\mathrm{Ca}^{2+}\right]_{\mathrm{i}}$ elicited by E2 or G-1 (Figures 2D,E) $\left(\mathrm{E} 2+\mathrm{CdCl}_{2}\right.$ : $56.24 \pm 9.51 \%$ vs. E2: $53.38 \pm 10.40 \%, n=41$ cells, $P>0.05$; $\mathrm{G}-1+\mathrm{CdCl}_{2}: 114.25 \pm 14.50 \%$ vs. G-1: $93.66 \pm 16.06 \%$, $n=28$ cells, $P>0.05$, Figure $2 \mathbf{H}$ ), whereas depletion of store $\mathrm{Ca}^{2+}$ with thapsigargin $(1 \mu \mathrm{M}, 5 \mathrm{~min})$ virtually prevented $\mathrm{E} 2$ or G-1 from inducing a $\mathrm{Ca}^{2+}$ rise (Figure 2F). Furthermore, treatment of SH-SY5Y cells with the PLC inhibitor U73122 $(3 \mu \mathrm{M})$ completely blocked the rapid $\mathrm{Ca}^{2+}$ rise in response to $\mathrm{E} 2$ or G-1 (Figures 2A,B, 3A-C). Analogously, E2 or G-1-induced $\mathrm{Ca}^{2+}$ rise was abolished in the presence of 2 -APB $(3 \mu \mathrm{M})$, an 


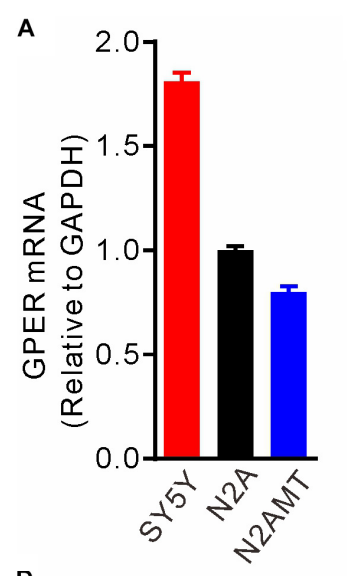

D

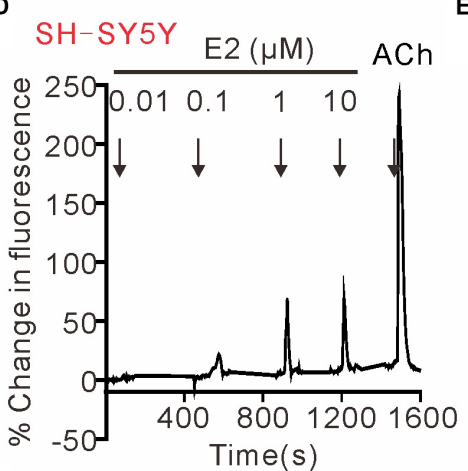

G
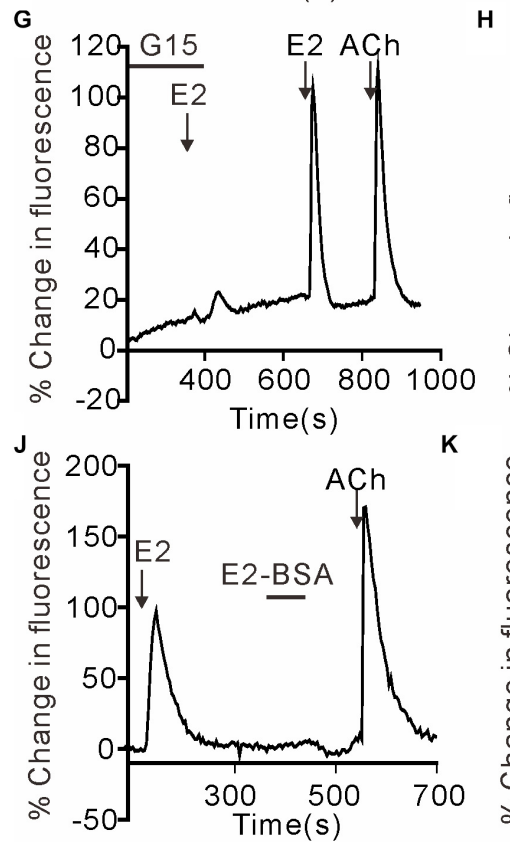

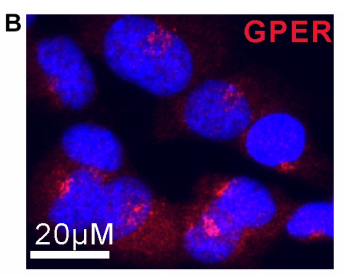

C

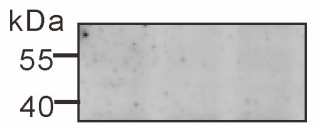

membrane GPER
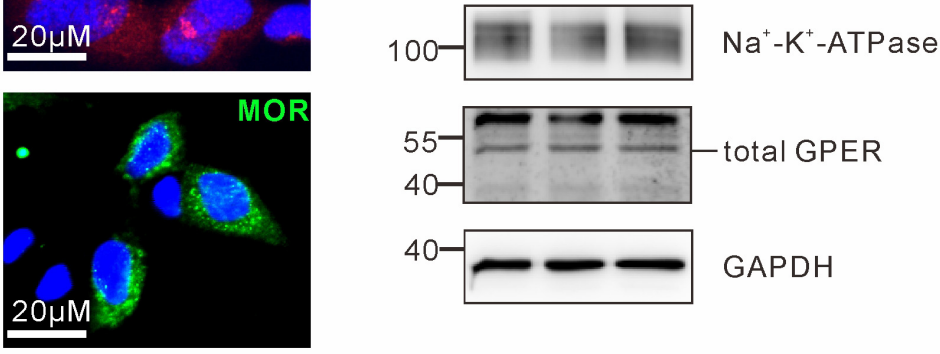

E
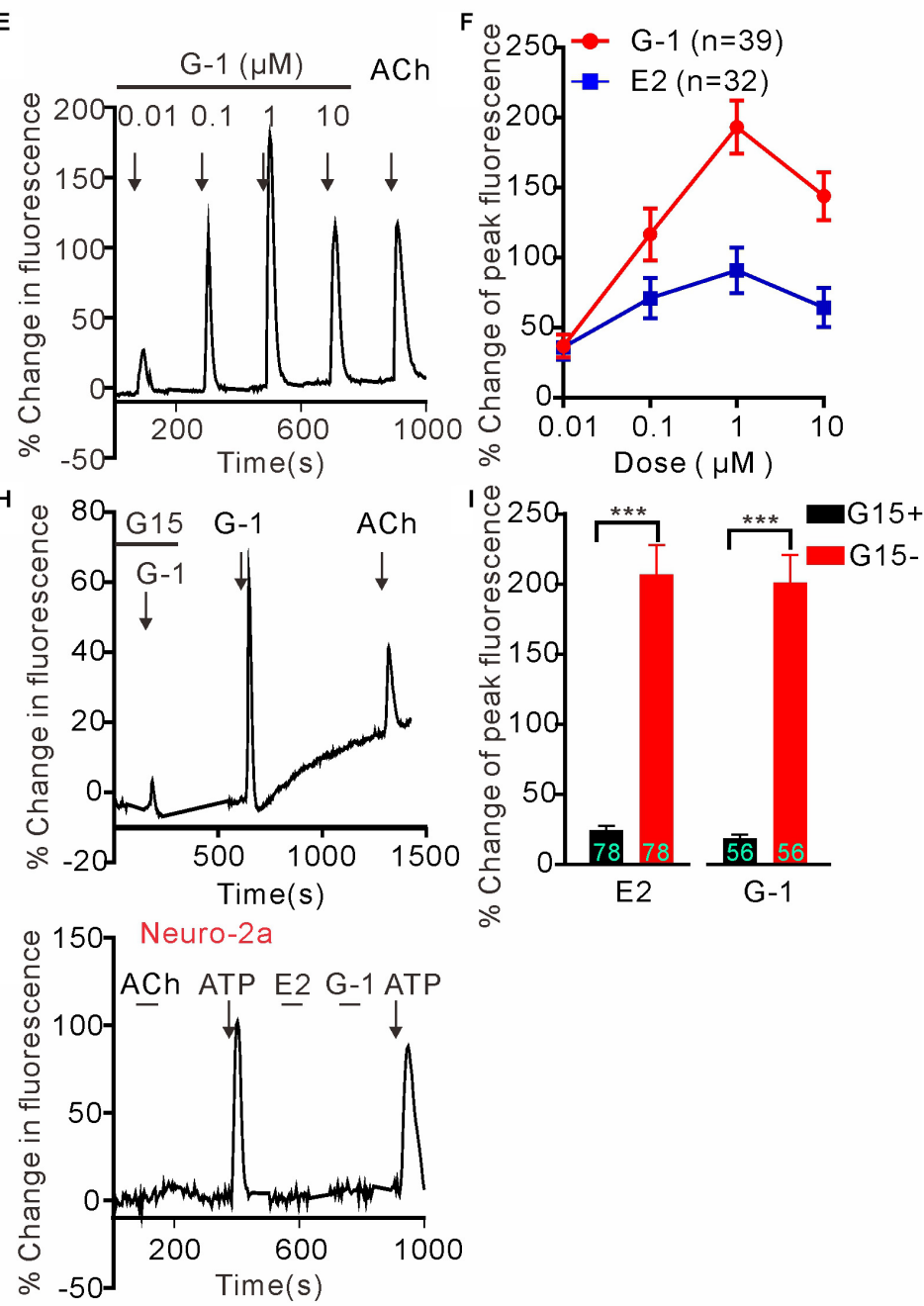

E2

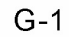

FIGURE 1 | G protein-coupled estrogen receptor mediates calcium rise in SH-SY5Y cells. (A) RT-PCR analysis shows relatively higher expression of GPER mRNA in SH-SY5Y cells than in Neuro-2a (N2A) cells. N2AMT is a line of Neuro-2a stably expressing human $\mu$ type opioid receptor (hMOR). (B) Immunofluorescent staining for GPER and MOR in SH-SY5Y cells. GPER immunofluorescence is located at certain perinuclear organelle. (C) Western blot detection of GPER in cytoplasmic membrane fraction vs. total protein. Whereas GPER immunoreactivity is abundant in the total protein samples, it could not be detected within the cytoplasmic membrane protein sample. (D-J) Fluo-4-based imaging of cytosolic [Ca ${ }^{2+}$ ] transients in response to GPER agonists 17- $\beta$ estradiol (E2) and G-1. Note E2 and G-1 both caused concentration-dependent rapid $\mathrm{Ca}^{2+}$ rise, which was prevented by GPER antagonist G15. The membrane impermeable BSA-conjugated E2 was unable to evoke a rapid $\mathrm{Ca}^{2+}$ rise. (K) Neither E2 nor G-1 was able to cause a $\mathrm{Ca}^{2+}$ rise in N2A cells. The example traces (D,E,G,H,J,K) are the average percentage change in fluorescence of 7-26 cells in one visual field. Values in bar graphs (F,I) are averaged peak percentage changes of $32 \sim 78$ cells from three to four independent tests. Note that the responses to the lowest concentration $(0.01 \mu \mathrm{M})$ of $\mathrm{E} 2$ or $\mathrm{G}-1$ in separate experiments were quite variable (e.g., $\mathbf{D}$,E), but on average the peak response to E2 or G-1 $(0.01 \mu \mathrm{M})$ were similar $(\mathbf{F}) .{ }^{* * *} P<0.001$, paired $t$-test. 

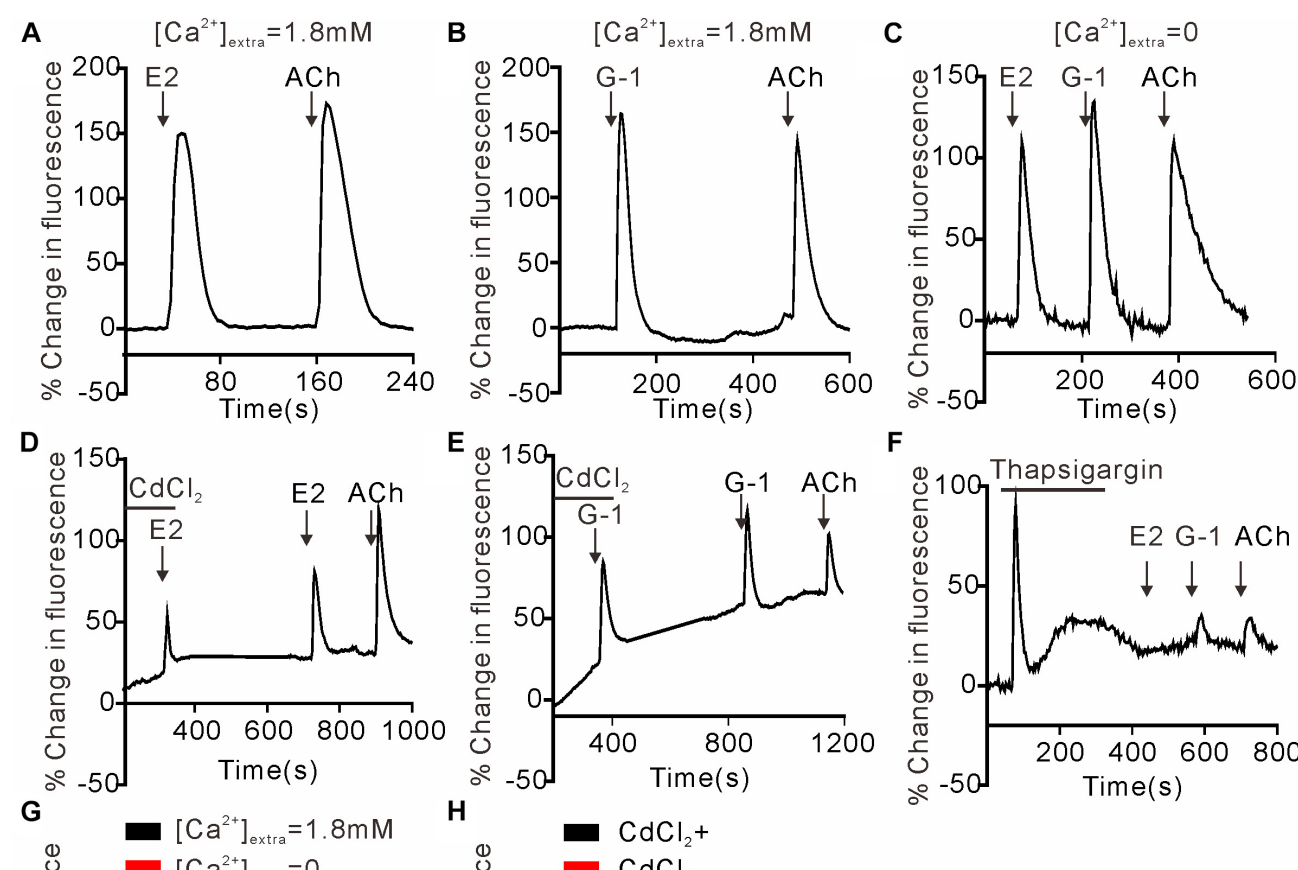

$\mathbf{F}$
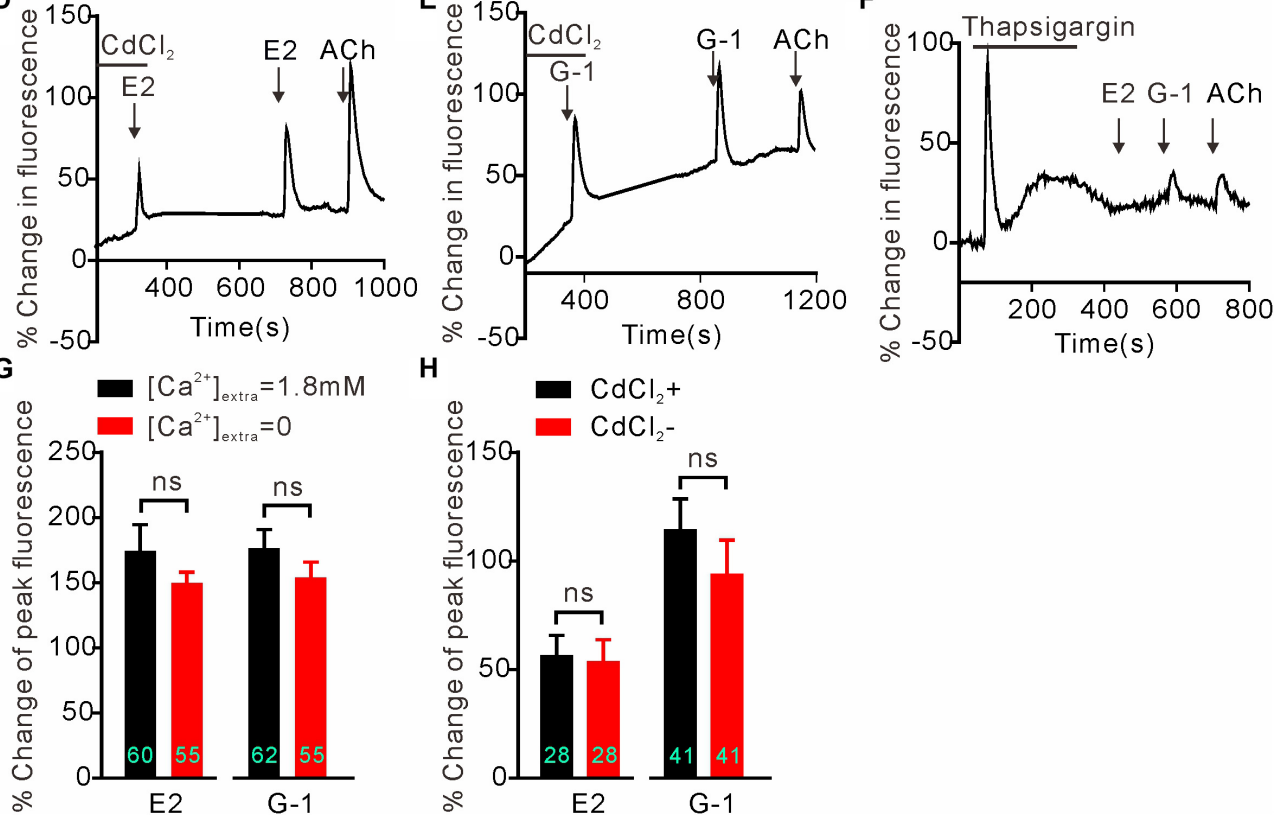

FIGURE 2 | Intracellular calcium rise elicited by E2 or G-1 was independent of calcium influx in SH-SY5Y cells. (A-C,G) E2 and G-1 both caused rapid Ca $2+$ rise with or without extracellular $\mathrm{Ca}^{2+}$. (D,E,H) The non-selective voltage-gated calcium channel blocker $\mathrm{CdCl}_{2}$ had no effect on the Ca2+ rise induced by $\mathrm{E}_{2}$ or $\mathrm{G}-1$. (F) Depletion of store $\mathrm{Ca}^{2+}$ using thapsigargin prevented E2 or G-1 or ACh from evoking a rapid $\mathrm{Ca}^{2+}$ rise. The example traces (A-F) are the average percentage change in fluorescence of 10-29 cells in one visual field. (G,H) Averaged peak percentage changes in fluorescence in different conditions. ns, not significant, unpaired $\mathbf{( G )}$ or paired $\mathbf{( H )} t$-test, $n=28 \sim 62$ cells from three to four independent tests.

IP3R inhibitor (Figures 3D,E) (E2 + 2-APB: $7.12 \pm 1.30 \%$ vs. E2: $231.5 \pm 16.41 \%, n=48$ cells, $P<0.001 ; \mathrm{G}-1+2$-APB: $22.01 \pm 2.73 \%$ vs. G- $1: 148.9 \pm 7.82 \%, n=48$ cells, $P<0.001$, Figure 3F). Therefore, activation of GPER may elicit PLC/IP3mediated store $\mathrm{Ca}^{2+}$ release.

\section{GPER Activation Stimulates PKC Isoforms}

Intracellular $\mathrm{Ca}^{2+}$ as an important second messenger may activate the $\mathrm{Ca}^{2+}$-dependent protein kinases (PKCs) characterized by translocation of cytosolic PKCs to the plasma membrane. Previous reports have implicated PKC $\alpha$ and PKCE in regulation of pain and $\mu$-opioid signaling (Bailey et al., 2009; Zheng et al., 2011; Illing et al., 2014). Hence we focused on these two PKC isoforms to test whether GPER-mediated $\mathrm{Ca}^{2+}$ signaling may stimulate PKCs. We took advantage of the biotin-avidin method to extract plasma membrane proteins and to detect the possible translocation/activation of PKC $\alpha$ and PKCE following GPER activation in SH-SY5Y cells. As a positive control, cells treated with the PKC agonist PMA $(1 \mu \mathrm{M})$ for $5 \mathrm{~min}$ manifested pronounced translocation of $\mathrm{PKC} \alpha$ and $\mathrm{PKC} \varepsilon$ to the plasma membrane (Figures $\mathbf{4 A , B}, \mathbf{G}, \mathbf{H}$ ). In a similar manner, a 5 min treatment of the cells with E2 or G-1 $(1 \mu \mathrm{M})$ significantly increased membrane translocation of $\mathrm{PKC} \alpha$ and PKC $\varepsilon$ (Figures 4C-F,I-L).

\section{GPER Activation Facilitates MOR Phosphorylation in PKC-Dependent} Manner

In the hypothalamus, estrogens may rapidly desensitize MOR probably by activating PLC, PKA, and PKCs and uncouple MOR from activating GIRK channels (Kelly et al., 1999). We therefore investigated whether activation of GPER may promote MOR phosphorylation in SH-SY5Y cells. As a positive control, cells 

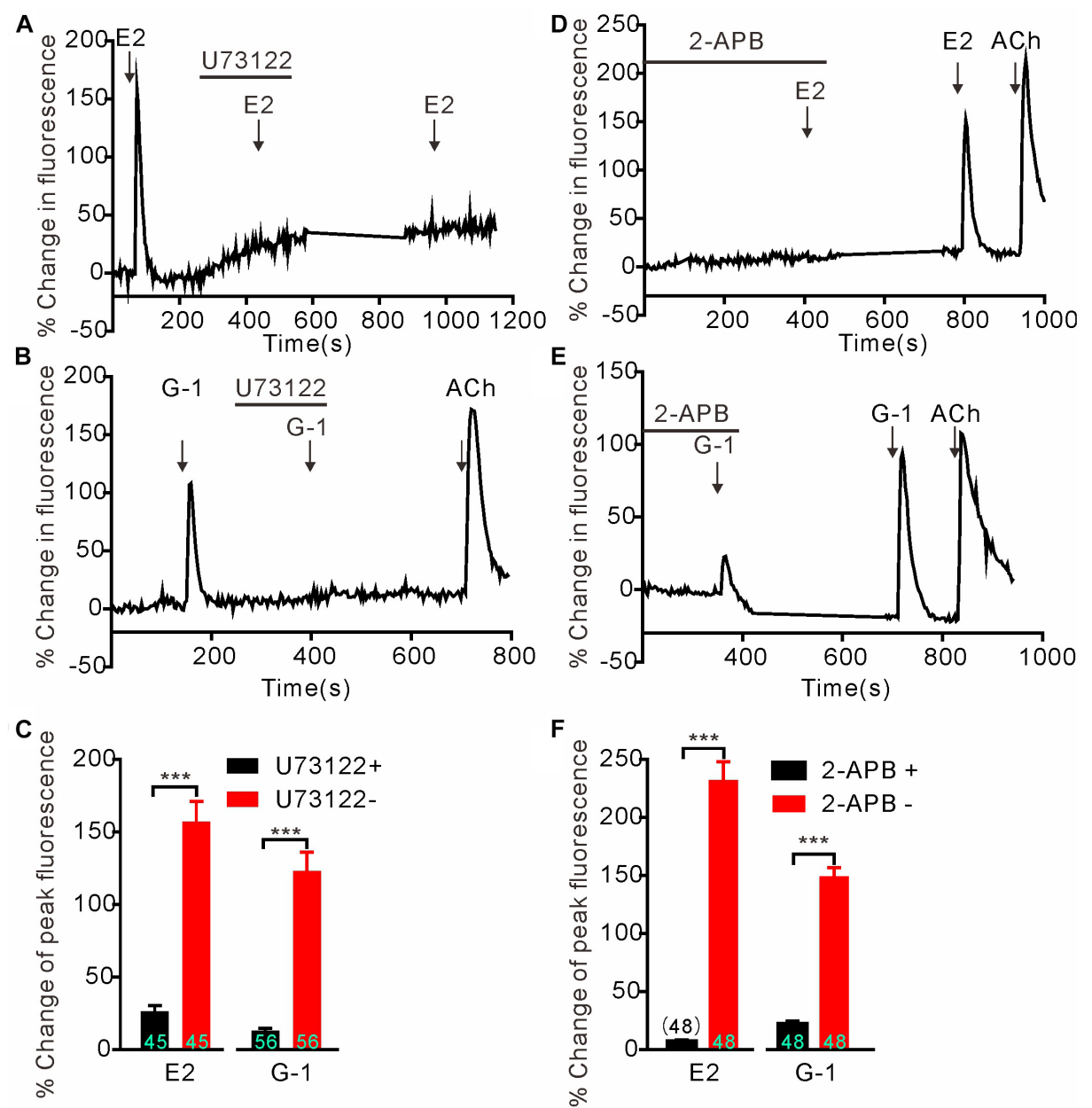

FIGURE 3 | G protein-coupled estrogen receptor-mediated rapid calcium rise in SH-SY5Y cells is via the PLC/IP3 pathway. (A-C) The PLC inhibitor U73122 (3 $\mu$ M) completely blocked the calcium response to E2 $(1 \mu \mathrm{M})$ and G-1 $(1 \mu \mathrm{M})$. (D-F) The store calcium release channel (IP3R) blocker, 2-APB, virtually abolished G-1 or E2-evoked calcium responses. The example traces (A,B,D,E) are the average percentage change in fluorescence of 16-25 cells in one visual field. (C,F) The averaged peak percentage changes in fluorescence in different conditions. ${ }^{* * *} P<0.001$, paired $t$-test. $n=45 \sim 56$ cells from three to four independent tests.

were treated with the PKC agonist PMA $(1 \mu \mathrm{M})$ for $30 \mathrm{~min}$, which resulted in an increase of phosphorylated MOR (pMOR) level compared with the vehicle group (Figure 5). Similarly, cells exposed to E2 or G-1 (1 $\mu \mathrm{M})$ also had significantly higher levels of pMOR, which was prevented by co-administration of panPKC inhibitor Ro 31-8820 (3 $\mu \mathrm{M}$, which inhibits PKC $\alpha$, PKC $\beta \mathrm{I}$, $\mathrm{PKC} \beta \mathrm{II}, \mathrm{PKC} \gamma$, and $\mathrm{PKC} \varepsilon$ ) (Figure 5). Therefore, activation of GPER may promote MOR phosphorylation in a PKCdependent manner.

\section{GPER-Mediated Rapid Calcium Signaling Elicits Indirect Genomic Effects}

Previous studies indicate that the rapid non-genomic estrogenic signaling via second messengers (such as cAMP or $\mathrm{Ca}^{2+}$ ) is also transmitted to the nucleus to affect gene transcription and protein synthesis, leading to an indirect (not via the classic nuclear receptor ER $\alpha / \beta$ ) genomic effect (Guo et al., 2002). To investigate whether GPER-mediated rapid $\mathrm{Ca}^{2+}$ signaling may elicit such indirect genomic effects, we exposed SH-SY5Y cells with E2 or G-1 and detected c-Fos, which is an immediate early gene that responds to extracellular signals. Cells were treated with E2 $(1 \mu \mathrm{M})$ or G-1 $(1 \mu \mathrm{M})$ for 15,30 , and $60 \mathrm{~min}$, respectively. Whole lysate western blot showed that both E2 and G-1 caused time-dependent increases in c-Fos protein expression (Figures 6A-C). Moreover, the E2 or G-1-induced $\mathrm{c}$-Fos expression was almost completely negated in the presence of the GPER antagonists G15, the IP3R inhibitor 2-APB, or the PLC inhibitor U73122 (Figures 6D-F). These results indicate that GPER-mediated rapid PLC/IP3-dependent $\mathrm{Ca}^{2+}$ signaling may be transmitted to the nucleus to regulate gene transcription and protein synthesis.

\section{DISCUSSION}

Estrogens, primarily $17 \beta$-estradiol (E2), are known to exert major influences on the nervous system with slow genomic and rapid 

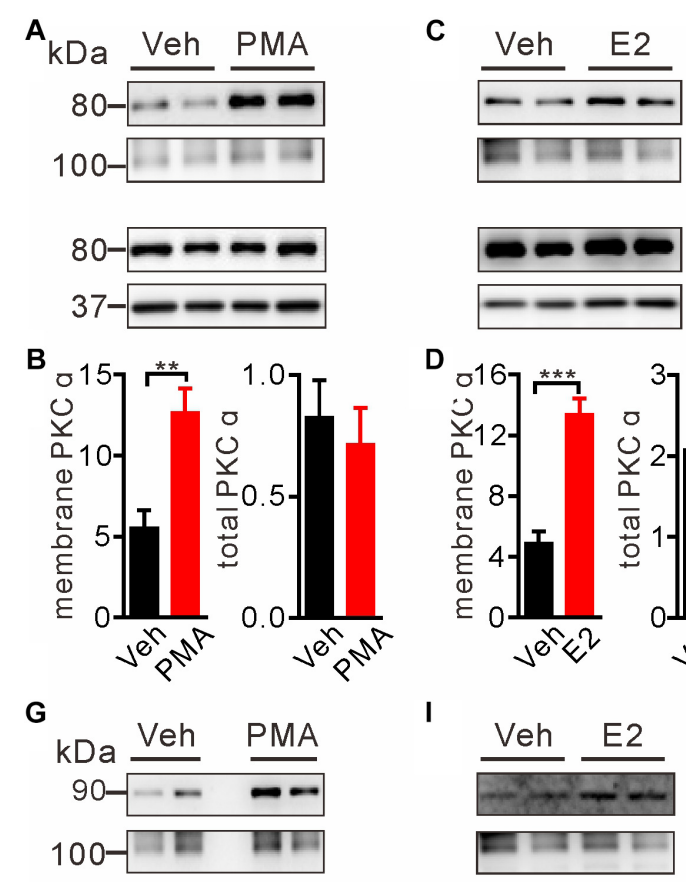

D

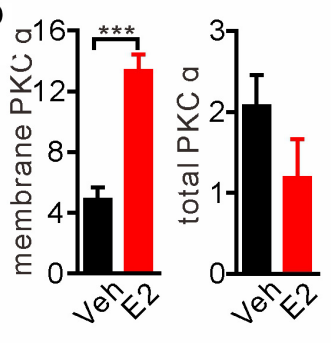

I
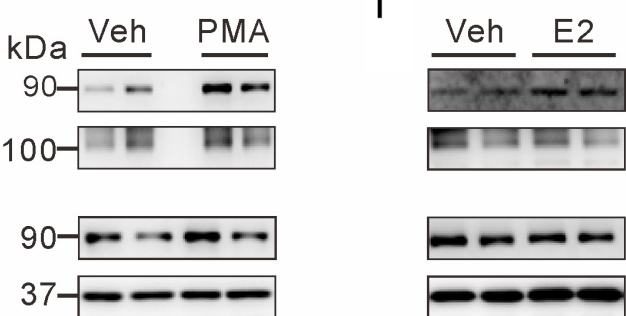

H

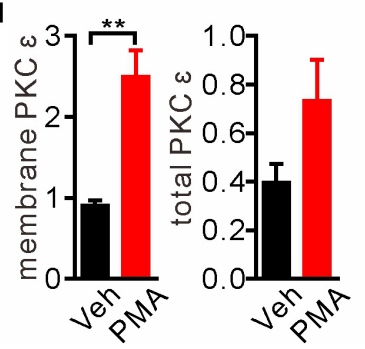

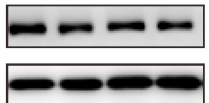

J

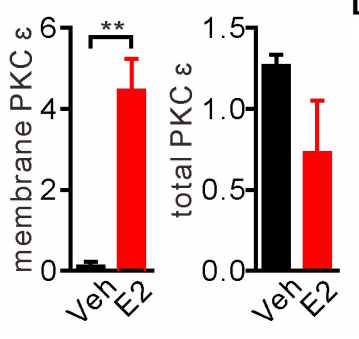

E

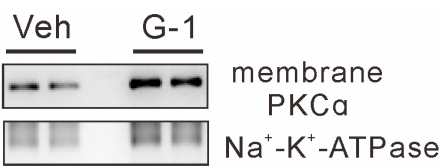

$-\infty-\infty$ total PKCa

GAPDH

$\mathbf{F}$

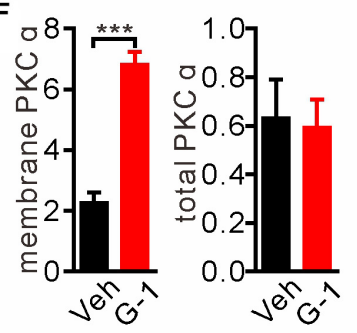

K
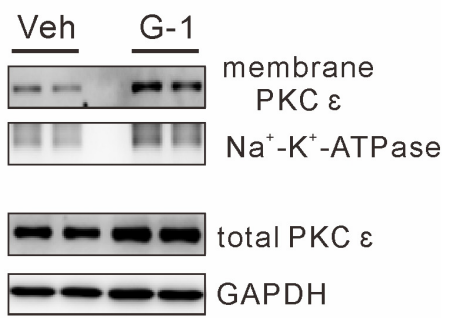

L

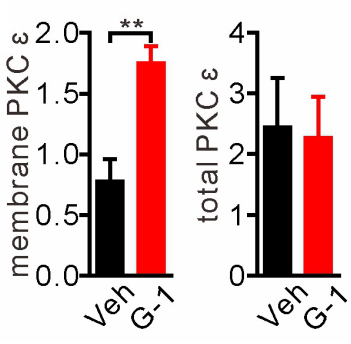

FIGURE 4 | E2 and G-1 promoted translocation of PKC isoforms to the plasma membrane. (A,B,G,H) Cells treated with the pan-PKC agonist PMA (1 $\mu$ M) for 5 min had significantly higher PKC $\alpha$ and PKC $\varepsilon$ in the plasma membrane protein samples, compared with vehicle-treated cells. (C,D,I,J) Cells treated with E2 (1 $\mu$ M) for 5 min had increased PKC $\alpha$ and PKC $\varepsilon$ in the plasma membrane protein samples as compared with cells treated with vehicle. (E,F,K,L) Cells treated with G-1 (1 $\mu$ M) for 5 min had increased PKC $\alpha$ and PKC $\varepsilon$ in the plasma membrane protein samples as compared with cells treated with vehicle. After detected PKC $\alpha$ bands (C,E), the nitrocellulose membrane was stripped and re-blocked by $5 \%$ fat-free dry milk in TBST, followed by incubation with PKC $\varepsilon$ primary antibody, then PKC $\varepsilon$ bands was detected $\mathbf{( I , K )}$. So the loading controls are the same. Membrane PKC $\alpha$ or PKC $\varepsilon$ is a relative value with $\mathrm{Na}^{+}-\mathrm{K}^{+}-\mathrm{ATPase}$ as the internal reference for plasma membrane protein; total PKC $\alpha$ or PKC $\varepsilon$ is the relative value with GAPDH as the internal reference for total protein. $* * P<0.01, * * * P<0.001$, unpaired $t$-test, averaged data from three to four independent experiments.

non-genomic effects. Whilst it is clear that two nuclear receptors, $\mathrm{ER} \alpha$ and $\mathrm{ER} \beta$, mediate the slow genomic effects, the receptor(s) responsible for the rapid non-genomic effects in the nervous system remain uncertain. The current study demonstrates that the human neuroblastoma SH-SY5Y cells endogenously express G protein-coupled estrogen receptor (GPER) and activation of GPER may induce a rapid increase in cytosolic $\mathrm{Ca}^{2+}$, which is due to PLC/IP3-dependent store $\mathrm{Ca}^{2+}$ release and is followed by PKC activation and MOR phosphorylation. Furthermore, GPERmediated $\mathrm{Ca}^{2+}$ signaling may also be transmitted to the nucleus to induce c-Fos expression. To the best of our knowledge, this is for the first time that GPER is shown to mediate calcium release and PKC-dependent phosphorylation of MOR in neuroblastoma cells. Our findings strongly support GPER as a mediator of the rapid non-genomic estrogenic effects in the nervous system.

$\mathrm{Ca}^{2+}$ as a ubiquitous intracellular messenger regulates diverse neuronal functions. $\mathrm{Ca}^{2+}$ may bind to synaptotagmin to trigger synaptic vesicle release (Emptage et al., 2001). $\mathrm{Ca}^{2+}$ also binds to calmodulin (CaM) to form $\mathrm{CaM}-\mathrm{Ca}^{2+}$ complex, activating $\mathrm{Ca}^{2+} / \mathrm{CaM}-$ dependent protein kinases (CAMKs) or the $\mathrm{Ca}^{2+} / \mathrm{CaM}$-dependent serine/threonine phosphatase calcineurin, which plays an important role in the regulation of synaptic plasticity (Yakel, 1997; Wayman et al., 2008; Kim et al., 2016; Sugawara et al., 2017). $\mathrm{Ca}^{2+}$ activates the 


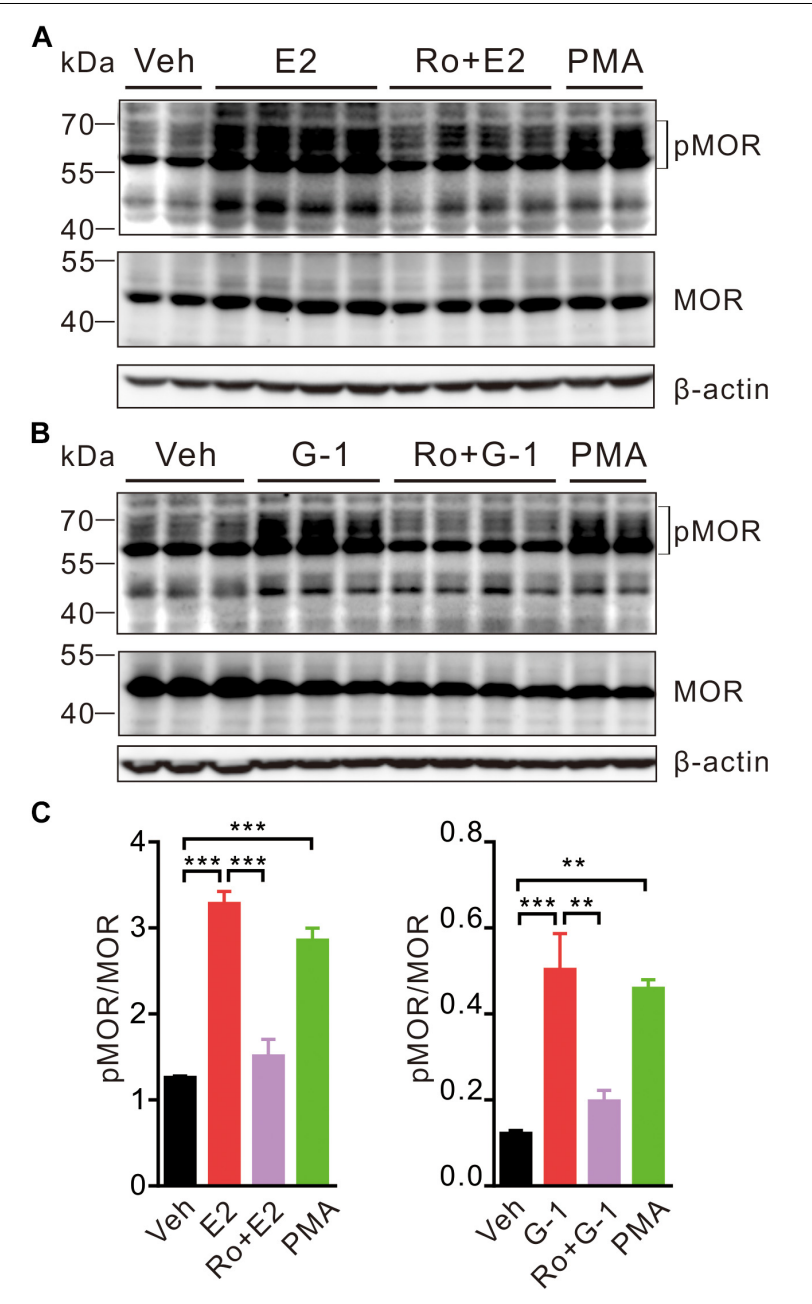

FIGURE 5 | E2 and G-1 stimulate phosphorylation of MOR in a PKC-dependent manner. (A,B) SH-SY5Y cells treated with PMA (1 $\mu \mathrm{M})$, E2 $(1 \mu \mathrm{M})$, or $\mathrm{G}-1$ (1 $\mu \mathrm{M})$ for 30 min showed increased level of phosphorylated MOR (pMOR) as compared with the vehicle group. In the presence of the pan-PKC inhibitor (Ro 31-8820, Ro, $3 \mu \mathrm{M}$ ), E2 and G-1 failed to increase pMOR expression. (C) The averaged pMOR level (relative to $\beta$-actin) in cells with different treatments. After detection of $\operatorname{pMOR}(\mathbf{A}, \mathbf{B})$, the nitrocellulose membrane was stripped and re-blocked by $5 \%$ fat-free dry milk in TBST, followed by incubation with MOR primary antibody, then MOR band was detected. ${ }^{* *} P<0.01,{ }^{* * *} P<0.001$, one-way ANOVA with Tukey's post hoc test, averaged data from three to four independent experiments.

$\mathrm{Ca}^{2+}$-dependent protein kinase (PKC) system to promote phosphorylation of various GPCRs and ion channels, thereby regulating neuronal excitability, synaptic transmission and plasticity (Ritter et al., 2012; Fukuchi et al., 2015b; Li et al., 2017; Rajagopal et al., 2017; Summers et al., 2019).

Previous studies indicate that estrogens may induce rapid changes in cytosolic $\mathrm{Ca}^{2+}$ in hippocampal neurons, hypothalamic astrocytes and embryonic midbrain dopaminergic neurons (Brailoiu et al., 2007; Noel et al., 2009; Kuo et al., 2010). Furthermore, E2 was found to rapidly desensitize $\mu$-opioid receptor (MOR) in hypothalamic neurons in PLC, PKA, and PKC-dependent manners, suggesting that $\mathrm{Ca}^{2+}$ signaling probably underlies estrogenic suppression of MOR function (Lagrange et al., 1997; Conde et al., 2016). MOR is best known for the regulation of pain and analgesia, but also plays important roles in regulation of reproductive behaviors, neuroprotection and cognition (Long et al., 2014; Jacobson et al., 2018; Liu et al., 2018; Vaidya et al., 2018). Therefore, it is of great interest to understand the identity of the receptor(s) which may mediate estrogenic suppression of MOR signaling.

The primary goal of this study is to test whether GPER can initiate rapid $\mathrm{Ca}^{2+}$ signaling and PKC-dependent phosphorylation of MOR in neuronal cells. To this end, we set to search for a neuronal cell line co-expressing GPER and MOR. qPCR showed that GPER mRNA appears to be relatively more abundant in the human neuroblastoma SH-SY5Y cells than in the murine Neuro-2a cells. Our immunofluorescent staining shows presence of GPER immunoreactivity at peri-nuclear sites and western blot assay could detect GPER immunoreactivity in whole-cell protein extract but not in membrane protein extract. Therefore, GPER is located intracellularly, in line with other reports indicating GPER being localized to the endoplasmic reticulum or the Golgi apparatus (Filardo and Thomas, 2005; Cheng et al., 2011). We found that GPER agonists E2/G-1 induced a rapid increase in intracellular calcium in SH-SY5Y cells but not in Neuro-2a cells. Currently, the reason for the lack of calcium response in Neuro-2a cells can only be speculated. One possibility is that GPER protein expression may be low in Neuro-2a cells, as suggested by the relative lower GPER mRNA than in SH-SY5Y cells. The other possibility is that GPER might be coupled to a different signaling cascade in this cell line. Due to the uncertain specificity of commercial GPER antibodies (in our hands, most GPER antibodies do not work very well with mouse samples), we have not been able to determine GPER protein expression in the murine-derived Neuro-2a cells. In this respect, it would be useful to test whether Neuro-2a cells transfected with GPER gene may respond to E2/G-1 with a calcium rise.

SH-SY5Y cells probably express $\mathrm{ER} \alpha, \mathrm{ER} \beta, \mathrm{G} \alpha_{\mathrm{q}}-\mathrm{mER}$ as well GPER (Barbati et al., 2012; Mateos et al., 2012; Nakaso et al., 2014; Gray et al., 2016; Shen et al., 2016; Cheng et al., 2017). However, the following lines of evidence from this study indicate that activation of GPER but not the classical ERs or ER variants may initiate rapid $\mathrm{Ca}^{2+}$ signaling: (1) SH-SY5Y but not Neuro-2a cells responded to E2 and the GPER selective agonist G-1 with rapid rises in cytosolic $\mathrm{Ca}^{2+}$ in concentration-dependent manners, consistent with the relative abundance of GPER mRNA in this cell line; (2) Either E2 or G-1-induced $\mathrm{Ca}^{2+}$ rise was blocked by the GPER antagonist G15; (3) The membrane impermeable E2BSA failed to cause a significant $\mathrm{Ca}^{2+}$ response, consistent with the intracellular localization of GPER in SH-SY5Y cells.

$\mathrm{E} 2$ has been shown to induce rapid $\mathrm{Ca}^{2+}$ influx through activation of L-type calcium channels (Wu et al., 2005, 2011; Zhao et al., 2005) or rapid store $\mathrm{Ca}^{2+}$ release in some neuronal cells (Beyer and Raab, 1998; Kuo et al., 2010). We found that GPER-mediated $\mathrm{Ca}^{2+}$ rise in SH-SY5Y cells was due to store release rather than $\mathrm{Ca}^{2+}$ entry since either E2 or G-1 still induced rapid increases in cytosolic $\mathrm{Ca}^{2+}$ in the extracellular $\mathrm{Ca}^{2+}$-free condition and in the presence of cadmium, a broad-spectrum voltage-dependent $\mathrm{Ca}^{2+}$ channel blocker. Depletion of the $\mathrm{Ca}^{2+}$ 


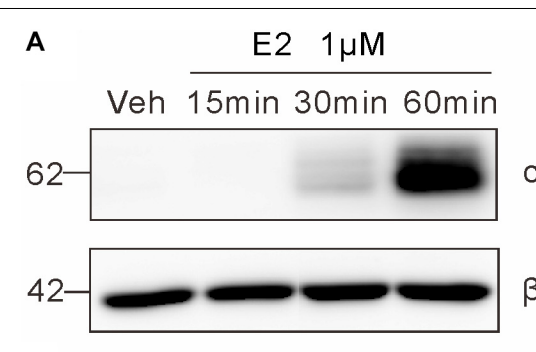

B

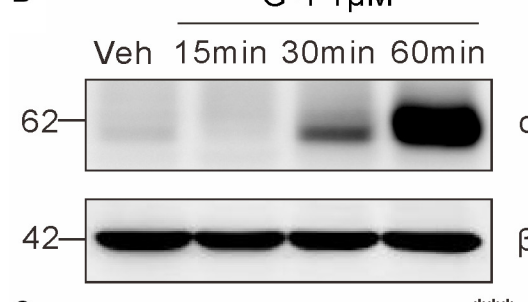

C
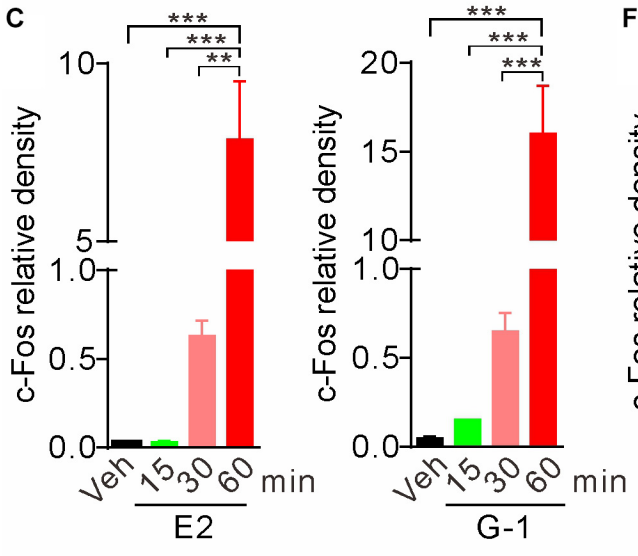

D

C-Fos

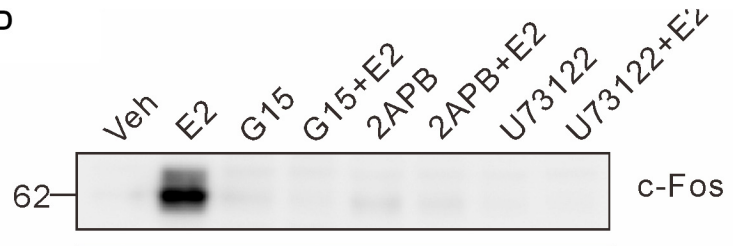

$\beta$-actin

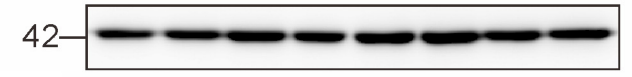

$\beta$-actin

E

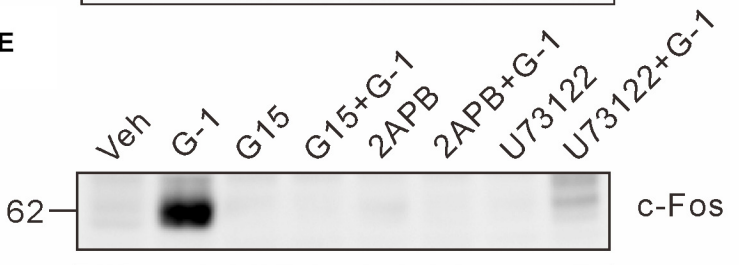

C-Fos
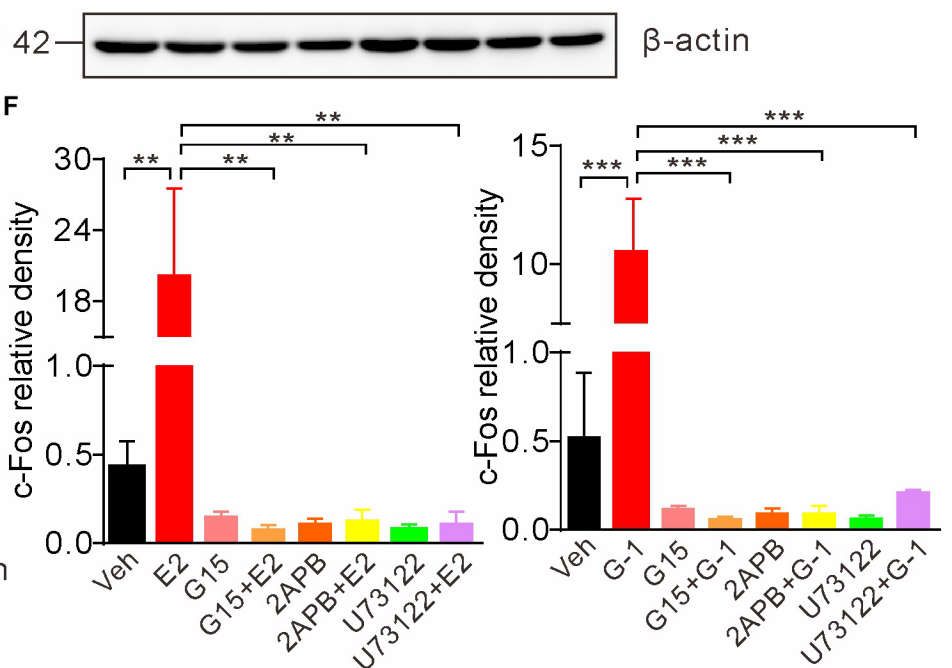

FIGURE 6 | Activation of GPER induces c-Fos expression in SH-SY5Y cells. (A-C) Cells treated with E2 (1 $\mu \mathrm{M})$ or G-1(1 $\mu \mathrm{M})$ showed time-dependent increases in c-Fos expression. (D-F) E2 and G-1-induced c-Fos expression was prevented by the GPER antagonist G15 (1 $\mu$ M), PLC inhibitor U73122 (1 $\mu$ M), and IP3R inhibitor 2-APB $(1 \mu \mathrm{M})$. c-Fos density was relative to $\beta$-actin. ${ }^{* *} P<0.05$, ${ }^{* * *} P<0.01$, one-way ANOVA with Tukey's post hoc test, averaged data from three independent experiments.

store with thapsigargin prevented E2 or G-1 from inducing a change in intracellular $\mathrm{Ca}^{2+}$ level. Furthermore, the IP3 receptor inhibitor $2-\mathrm{APB}$ and the PLC inhibitor U73122 virtually abolished either E2 or G-1-induced $\mathrm{Ca}^{2+}$ response, confirming activation of GPER induces store $\mathrm{Ca}^{2+}$ release through PLC and IP3 pathway.

Previously, Grassi et al. (2015) reported that estrogen receptor modulator raloxifene may down-regulate vasopressin mRNA in SH-SY5Y cells. By using G-1, G-15 and a PKC inhibitor, authors concluded that the raloxifene effect was mediated by GPER and PKC. In the present study, we were able to confirm that GPER-initiated $\mathrm{Ca}^{2+}$ signaling may activate PKCs and consequently promote phosphorylation of MOR. $\mathrm{PKC} \alpha, \mathrm{PKC} \varepsilon$, and $\mathrm{PKC} \gamma$ promote the phosphorylation of Serine 363, Threonine 370, and Serine 375 at C-terminal of MOR, which has been implicated in the development of pain and morphine tolerance (Zeitz et al., 2001; Hua et al., 2002; Bjornstrom and Sjoberg, 2005; Newton et al., 2007; Smith et al., 2007; Doll et al., 2011; Bowman et al., 2015).
We found that activation of GPER in SH-SY5Y cells promoted membrane translocation of PKC $\alpha$ and $\mathrm{PKC} \varepsilon$ and elevated the expression of phosphorylated-MOR (pMOR), which was negated by the PKC inhibitor Ro 31-8820. These data reveal a novel estrogenic signaling cascade mediated by GPER which ultimately leads to phosphorylation and desensitization of MOR. This signaling mechanism may be relevant to the welldocumented gender dymorphisms of pain, morphine analgesia, neuroprotection and cognition as well as the regulation of reproductive behaviors.

Previous studies indicate that the rapid non-genomic estrogenic signaling may also alter gene transcription (Guo et al., 2002; Bjornstrom and Sjoberg, 2005). In a prostate cancer cell (PC-3) line, G-1 may inhibit prostate cancer cell (PC3) growth, which was mediated through GPER, followed by activation of c-jun/c-fos (Chan et al., 2010). On the other hand, an increase in cytosolic $\mathrm{Ca}^{2+}$ may stimulate c-Fos expression, accounting for the neuronal activity-dependent immediate early gene expression and long lasting changes of neural functions 
(Fukuchi et al., 2015a). Hence we tested whether GPER-mediated $\mathrm{Ca}^{2+}$ rise may stimulate c-Fos expression. Indeed either E2 or G-1 stimulated c-Fos expression within $30 \mathrm{~min}$, which was prevented in the presence of the GPER antagonist G15, the IP3R blocker 2APB or the PLC inhibitor U73122. Therefore, GPERmediated rapid $\mathrm{Ca}^{2+}$ signaling may also be transmitted to the nucleus leading to the indirect (i.e., not via the nuclear recetpor, $\mathrm{ER} \alpha$ or $\mathrm{ER} \beta$ ) genomic effects.

In the present work, we did not attempt to identify the G protein subtype coupled to GPER. Nevertheless, the profile of the E2/G-1-induced calcium and PKC responses was reminiscent of the Gq-mER-mediated effects previously reported by Qiu et al. (2003) in hypothalamic proopiomelanocortin (POMC) neurons. They showed that E2 rapidly attenuated the potency of $\mathrm{GABA}_{\mathrm{B}}$ agonist to activate the GIRK current in POMC neurons and the signaling cascade involved $\mathrm{G} \alpha_{\mathrm{q}}$-mediated PLC activation upstream of PKC $\delta$, PKA and changes in gene transcription. The effects were mimicked by BSA-conjugated E2 and a nonsteroidal compound STX that does not bind ER $\alpha$ or ER $\beta$, leading to the proposal of a Gq-coupled membrane-associated estrogen (STX) receptor (Gq-mER). Although intracellular calcium was not measured in that study, it is conceivable that activation of GqmER may also signal through IP3-mediated store calcium release and activation of calcium-dependent PKC isoforms, similarly to the GPER-mediated signaling shown in the current study. The molecular identity of Gq-mER is still unknown. It would be interesting to examine whether Gq-mER and GPER are related or separate mechanisms for rapid estrogenic signaling.

\section{CONCLUSION}

The present study revealed a novel GPER-mediated estrogenic signaling cascade in neuroblastoma cells. Estrogens may activate the intracellularly located GPER to trigger rapid PLC/IP3dependent store $\mathrm{Ca}^{2+}$ release, which in turn activates PKC isoforms to phosphorylate the $\mu$ opioid receptor. The rapid $\mathrm{Ca}^{2+}$

\section{REFERENCES}

Bailey, C. P., Oldfield, S., Llorente, J., Caunt, C. J., Teschemacher, A. G., Roberts, L., et al. (2009). Involvement of PKC alpha and G-protein-coupled receptor kinase 2 in agonist-selective desensitization of mu-opioid receptors in mature brain neurons. Br. J. Pharmacol. 158, 157-164. doi: 10.1111/j.1476-5381.2009. 00140.x

Barbati, C., Pierdominici, M., Gambardella, L., Malchiodi Albedi, F., Karas, R. H., Rosano, G., et al. (2012). Cell surface estrogen receptor alpha is upregulated during subchronic metabolic stress and inhibits neuronal cell degeneration. PLoS One 7:e42339. doi: 10.1371/journal.pone.0042339

Beyer, C., and Raab, H. (1998). Nongenomic effects of oestrogen: embryonic mouse midbrain neurones respond with a rapid release of calcium from intracellular stores. Eur. J. Neurosci. 10, 255-262. doi: 10.1046/j.1460-9568.1998. 00045.x

Bjornstrom, L., and Sjoberg, M. (2005). Mechanisms of estrogen receptor signaling: convergence of genomic and nongenomic actions on target genes. Mol. Endocrinol. 19, 833-842. doi: 10.1210/me.2004-0486

Bologa, C. G., Revankar, C. M., Young, S. M., Edwards, B. S., Arterburn, J. B., Kiselyov, A. S., et al. (2006). Virtual and biomolecular screening converge on a selective agonist for GPR30. Nat Chem Biol. 2, 207-212. doi: 10.1038/ nchembio775 signaling may also be transmitted to the nucleus to impact on gene transcription. Such signaling cascade may play important roles in the regulation of opioid signaling in the brain.

\section{DATA AVAILABILITY STATEMENT}

All datasets generated for this study are included in the article/supplementary material.

\section{AUTHOR CONTRIBUTIONS}

All authors participated in the development of this research and drafting of the manuscript. WR, XS, and GZ made substantial contributions to the conception or design of the work, critically revised the manuscript, supervised the experiments and data analysis, acquired funding, designed the experiments, and analyzed the data. XD, TG, and PG performed the experiments and participated in the analysis of results. YM and LD participated in the immunofluorescence staining experiments. $\mathrm{YZ}$ and PL participated in the calcium imaging experiments.

\section{FUNDING}

This work was funded by the National Natural Science Foundation of China (Grants \#81570493 and \#81873728), the Science and Technology Commission of Shanghai Municipality (Grant \#18JC1420302), and Xin Hua Hospital (Grant \#JZPI201705).

\section{ACKNOWLEDGMENTS}

The authors wish to thank Dr. Yu Qiu for the gift of Neuroa cell lines.

Bowman, S. L., Soohoo, A. L., Shiwarski, D. J., Schulz, S., Pradhan, A. A., and Puthenveedu, M. A. (2015). Cell-autonomous regulation of Mu-opioid receptor recycling by substance P. Cell Rep. 10, 1925-1936. doi: 10.1016/j.celrep.2015. 02.045

Brailoiu, E., Dun, S. L., Brailoiu, G. C., Mizuo, K., Sklar, L. A., Oprea, T. I., et al. (2007). Distribution and characterization of estrogen receptor G proteincoupled receptor 30 in the rat central nervous system. J. Endocrinol. 193, 311-321. doi: 10.1677/JOE-07-0017

Chan, Q. K., Lam, H. M., Ng, C. F., Lee, A. Y., Chan, E. S., Ng, H. K., et al. (2010). Activation of GPR30 inhibits the growth of prostate cancer cells through sustained activation of Erk1/2, c-jun/c-fos-dependent upregulation of p21, and induction of G(2) cell-cycle arrest. Cell Death Differ. 17, 1511-1523. doi: 10. 1038/cdd.2010.20

Chen, W. C., Cheng, J. S., Chou, K. J., Tang, K. Y., Huang, J. K., Tseng, L. L., et al. (2002). Effect of $17 \beta$-estradiol on intracellular $\mathrm{Ca}(2)+$ levels in renal tubular cells. Pharmacology 64, 84-90. doi: 10.1159/000056155

Cheng, S. B., Quinn, J. A., Graeber, C. T., and Filardo, E. J. (2011). Downmodulation of the G-protein-coupled estrogen receptor, GPER, from the cell surface occurs via a trans-Golgi-proteasome pathway. J. Biol. Chem. 286, 22441-22455. doi: 10.1074/jbc.M111.224071

Cheng, Y. F., Zhu, G., Wu, Q. W., Xie, Y. S., Jiang, Y., Guo, L., et al. (2017). GPR30 activation contributes to the puerarin-mediated neuroprotection in 
MPP(+)-Induced SH-SY5Y cell death. J. Mol. Neurosci. 61, 227-234. doi: 10. 1007/s12031-016-0856-y

Conde, K., Meza, C., Kelly, M. J., Sinchak, K., and Wagner, E. J. (2016). Estradiol rapidly attenuates ORL-1 receptor-mediated inhibition of proopiomelanocortin neurons via Gq-Coupled, membrane-initiated signaling. Neuroendocrinology 103, 787-805. doi: 10.1159/000443765

Deliu, E., Brailoiu, G. C., Arterburn, J. B., Oprea, T. I., Benamar, K., Dun, N. J., et al. (2012). Mechanisms of G protein-coupled estrogen receptor-mediated spinal nociception. J. Pain. 13, 742-754. doi: 10.1016/j.jpain.2012.05.011

Dennis, M. K., Burai, R., Ramesh, C., Petrie, W. K., Alcon, S. N., Nayak, T. K., et al. (2009). In vivo effects of a GPR30 antagonist. Nat. Chem. Biol. 5, 421-427. doi: 10.1038/nchembio.168

Doll, C., Konietzko, J., Pöll, F., Koch, T., Höllt, V., and Schulz, S. (2011). Agonist-selective patterns of mu-opioid receptor phosphorylation revealed by phosphosite-specific antibodies. Br. J. Pharmacol. 164, 298-307. doi: 10.1111/j. 1476-5381.2011.01382.x

Dun, S. L., Brailoiu, G. C., Gao, X., Brailoiu, E., Arterburn, J. B., Prossnitz, E. R., et al. (2009). Expression of estrogen receptor GPR30 in the rat spinal cord and in autonomic and sensory ganglia. J. Neurosci. Res. 87, 1610-1619. doi: $10.1002 /$ jnr. 21980

Emptage, N. J., Reid, C. A., and Fine, A. (2001). Calcium stores in hippocampal synaptic boutons mediate short-term plasticity, store-operated Ca2+ entry, and spontaneous transmitter release. Neuron 29, 197-208. doi: 10.1016/S08966273(01)00190-8

Filardo, E. J., and Thomas, P. (2005). GPR30: a seven-transmembrane-spanning estrogen receptor that triggers EGF release. Trends Endocrinol. Metab. 16, 362-367. doi: 10.1016/j.tem.2005.08.005

Fukuchi, M., Kanesaki, K., Takasaki, I., Tabuchi, A., and Tsuda, M. (2015a). Convergent effects of $\mathrm{Ca}(2+)$ and cAMP signals on the expression of immediate early genes in neurons. Biochem. Biophys. Res. Commun. 466, 572-577. doi: 10.1016/j.bbrc.2015.09.084

Fukuchi, M., Tabuchi, A., Kuwana, Y., Watanabe, S., Inoue, M., Takasaki, I., et al. (2015b). Neuromodulatory effect of galphas- or galphaq-coupled G-protein-coupled receptor on NMDA receptor selectively activates the NMDA receptor/Ca2+/calcineurin/cAMP response element-binding protein-regulated transcriptional coactivator 1 pathway to effectively induce brain-derived neurotrophic factor expression in neurons. J. Neurosci. 35, 5606-5624. doi: 10.1523/JNEUROSCI.3650-14.2015

Grassi, D., Ghorbanpoor, S., Acaz-Fonseca, E., Ruiz-Palmero, I., and Garcia-Segura, L. M. (2015). The selective estrogen receptor modulator raloxifene regulates arginine-vasopressin gene expression in human female neuroblastoma cells through $\mathrm{G}$ protein-coupled estrogen receptor and ERK signaling. Endocrinology 156, 3706-3716. doi: 10.1210/en.2014-2010

Gray, N. E., Zweig, J. A., Kawamoto, C., Quinn, J. F., and Copenhaver, P. F. (2016). STX, a novel membrane estrogen receptor ligand, protects against Amyloidbeta toxicity. J. Alzheimers Dis. 51, 391-403. doi: 10.3233/JAD- 150756

Guo, Z., Krucken, J., Benten, W. P., and Wunderlich, F. (2002). Estradiol-induced nongenomic calcium signaling regulates genotropic signaling in macrophages. J. Biol. Chem. 277, 7044-7050. doi: 10.1074/jbc.M109808200

Hazell, G. G., Yao, S. T., Roper, J. A., Prossnitz, E. R., O'Carroll, A. M., and Lolait, S. J. (2009). Localisation of GPR30, a novel G protein-coupled oestrogen receptor, suggests multiple functions in rodent brain and peripheral tissues. J. Endocrinol. 202, 223-236. doi: 10.1677/JOE-09-0066

Hua, X. Y., Moore, A., Malkmus, S., Murray, S. F., Dean, N., Yaksh, T. L., et al. (2002). Inhibition of spinal protein kinase $C$ alpha expression by an antisense oligonucleotide attenuates morphine infusion-induced tolerance. Neuroscience 113, 99-107. doi: 10.1016/\$0306-4522(02)00157-4

Huang, J. K., and Jan, C. R. (2001). Mechanism of estrogens-induced increases in intracellular $\mathrm{Ca}(2)+$ in PC3 human prostate cancer cells. Prostate 47, 141-148. doi: 10.1002/pros.1057

Illing, S., Mann, A., and Schulz, S. (2014). Heterologous regulation of agonistindependent mu-opioid receptor phosphorylation by protein kinase C. Br. J. Pharmacol. 171, 1330-1340. doi: 10.1111/bph.12546

Jacobson, M. L., Wulf, H. A., Browne, C. A., and Lucki, I. (2018). Opioid modulation of cognitive impairment in depression. Prog. Brain Res. 239, 1-48. doi: $10.1016 /$ bs.pbr.2018.07.007

Jensen, E. V., and Desombre, E. R. (1973). Estrogen-receptor interaction. Science 182, 126-134. doi: 10.1126/science.182.4108.126
Kelly, M. J., Lagrange, A. H., Wagner, E. J., and Rønnekleiv, O. K. (1999). Rapid effects of estrogen to modulate $\mathrm{G}$ protein-coupled receptors via activation of protein kinase A and protein kinase C pathways. Steroids 64, 64-75. doi: 10. 1016/S0039-128X(98)00095-6

Kelly, M. J., and Ronnekleiv, O. K. (2009). Control of CNS neuronal excitability by estrogens via membrane-initiated signaling. Mol. Cell. Endocrinol. 308, 17-25. doi: $10.1016 /$ j.mce.2009.03.008

Kim, K., Saneyoshi, T., Hosokawa, T., Okamoto, K., and Hayashi, Y. (2016). Interplay of enzymatic and structural functions of CaMKII in long-term potentiation. J. Neurochem. 139, 959-972. doi: 10.1111/jnc.13672

Kuhn, J., Dina, O. A., Goswami, C., Suckow, V., Levine, J. D., and Hucho, T. (2008). GPR30 estrogen receptor agonists induce mechanical hyperalgesia in the rat. Eur. J. Neurosci. 27, 1700-1709. doi: 10.1111/j.1460-9568.2008.06131.x

Kuiper, G. G., Enmark, E., Pelto-Huikko, M., Nilsson, S., and Gustafsson, J. A. (1996). Cloning of a novel receptor expressed in rat prostate and ovary. Proc. Natl. Acad. Sci. U.S.A. 93, 5925-5930. doi: 10.1073/pnas.93.12.5925

Kuo, J., Hamid, N., Bondar, G., Prossnitz, E. R., and Micevych, P. (2010). Membrane estrogen receptors stimulate intracellular calcium release and progesterone synthesis in hypothalamic astrocytes. J. Neurosci. 30, 1295012957. doi: 10.1523/JNEUROSCI.1158-10.2010

Lagrange, A. H., Rønnekleiv, O. K., and Kelly, M. J. (1997). Modulation of G protein-coupled receptors by an estrogen receptor that activates protein kinase A. Mol. Pharmacol. 51, 605-612. doi: 10.1124/mol.51.4.605

Li, S., Zeng, J., Wan, X., Yao, Y., Zhao, N., Yu, Y., et al. (2017). Enhancement of spinal dorsal horn neuron NMDA receptor phosphorylation as the mechanism of remifentanil induced hyperalgesia: roles of PKC and CaMKII. Mol. Pain 13:1744806917723789. doi: 10.1177/1744806917723789

Liu, A., Zhang, H., Qin, F., Wang, Q., Sun, Q., Xie, S., et al. (2018). Sex Associated Differential Expressions of the Alternatively Spliced Variants mRNA of OPRM1 in Brain Regions of C57BL/6 Mouse. Cell. Physiol. Biochem. 50, 1441-1459. doi: $10.1159 / 000494644$

Long, N., Long, B., Mana, A., Le, D., Nguyen, L., Chokr, S., et al. (2017). Tamoxifen and ICI 182,780 activate hypothalamic G protein-coupled estrogen receptor 1 to rapidly facilitate lordosis in female rats. Horm. Behav. 89, 98-103. doi: 10.1016/j.yhbeh.2016.12.013

Long, N., Serey, C., and Sinchak, K. (2014). 17beta-estradiol rapidly facilitates lordosis through $G$ protein-coupled estrogen receptor 1 (GPER) via deactivation of medial preoptic nucleus mu-opioid receptors in estradiol primed female rats. Horm. Behav. 66, 663-666. doi: 10.1016/j.yhbeh.2014. 09.008

Lu, Y., Jiang, Q., Yu, L., Lu, Z. Y., Meng, S. P., Su, D., et al. (2013). 17beta-estradiol rapidly attenuates $\mathrm{P} 2 \mathrm{X} 3$ receptor-mediated peripheral pain signal transduction via ERalpha and GPR30. Endocrinology 154, 2421-2433. doi: 10.1210/en.20122119

Mateos, L., Persson, T., Katoozi, S., Gil-Bea, F. J., and Cedazo-Minguez, A. (2012). Estrogen protects against amyloid-beta toxicity by estrogen receptor alphamediated inhibition of Daxx translocation. Neurosci. Lett. 506, 245-250. doi: 10.1016/j.neulet.2011.11.016

Mosselman, S., Polman, J., and Dijkema, R. (1996). ER $\beta$ : identification and characterization of a novel human estrogen receptor. FEBS. Lett. 392, 49-53. doi: 10.1016/0014-5793(96)00782-X

Nakaso, K., Tajima, N., Horikoshi, Y., Nakasone, M., Hanaki, T., Kamizaki, K., et al. (2014). The estrogen receptor beta-PI3K/Akt pathway mediates the cytoprotective effects of tocotrienol in a cellular Parkinson's disease model. Biochim. Biophys. Acta 1842, 1303-1312. doi: 10.1016/j.bbadis.2014.04.008

Newton, P. M., Kim, J. A., McGeehan, A. J., Paredes, J. P., Chu, K., Wallace, M. J., et al. (2007). Increased response to morphine in mice lacking protein kinase $C$ epsilon. Genes Brain Behav. 6, 329-338. doi: 10.1111/j.1601-183X.2006.00261.x

Noel, S. D., Keen, K. L., Baumann, D. I., Filardo, E. J., and Terasawa, E. (2009). Involvement of G protein-coupled receptor 30 (GPR30) in rapid action of estrogen in primate LHRH neurons. Mol. Endocrinol. 23, 349-359. doi: 10.1210/ me.2008-0299

Ogawa, S., Tsukahara, S., Choleris, E., and Vasudevan, N. (2018). Estrogenic regulation of social behavior and sexually dimorphic brain formation. Neurosci. Biobehav. Rev. doi: 10.1016/j.neubiorev.2018.10.012 [Epub ahead of print].

Paech, K., Webb, P., Kuiper, G. G., Nilsson, S., Gustafsson, J., Kushner, P. J., et al. (1997). Differential ligand activation of estrogen receptors ER $\alpha$ and ER $\beta$ at AP1 sites. Science 277, 1508-1510. doi: 10.1126/science.277.5331.1508 
Paletta, P., Sheppard, P. A. S., Matta, R., Ervin, K. S. J., and Choleris, E. (2018). Rapid effects of estrogens on short-term memory: possible mechanisms. Horm. Behav. 104, 88-99. doi: 10.1016/j.yhbeh.2018.05.019

Petrovic, S., Velickovic, N., Stanojevic, I., Milosevic, M., Drakulic, D., Stanojlovic, M., et al. (2011). Inhibition of mitochondrial $\mathrm{Na}$-dependent $\mathrm{Ca}(2)+$ efflux by 17 beta-estradiol in the rat hippocampus. Neuroscience 192, 195-204. doi: 10.1016/j.neuroscience.2011.06.030

Picotto, G., Vazquez, G., and Boland, R. (1999). 17 $\beta$-oestradiol increases intracellular $\mathrm{Ca}(2)+$ concentration in rat enterocytes. Potential role of phospholipase C-dependent store-operated $\mathrm{Ca}(2)+$ influx. Biochem. J. 339, 71-77. doi: 10.1042/bj3390071

Qiu, J., Bosch, M. A., Tobias, S. C., Grandy, D. K., Scanlan, T. S., Ronnekleiv, O. K., et al. (2003). Rapid signaling of estrogen in hypothalamic neurons involves a novel G-protein-coupled estrogen receptor that activates protein kinase C. J. Neurosci. 23, 9529-9540. doi: 10.1523/JNEUROSCI.23-29-09529. 2003

Rainville, J., Pollard, K., and Vasudevan, N. (2015). Membrane-initiated nongenomic signaling by estrogens in the hypothalamus: cross-talk with glucocorticoids with implications for behavior. Front. Endocrinol. 6:18. doi: $10.3389 /$ fendo. 2015.00018

Rajagopal, S., Burton, B. K., Fields, B. L., El, I. O., and Kamatchi, G. L. (2017). Stimulatory and inhibitory effects of PKC isozymes are mediated by serine/threonine PKC sites of the Cav2.3alphal subunits. Arch. Biochem. Biophys. 621, 24-30. doi: 10.1016/j.abb.2017.04.002

Revankar, C. M., Cimino, D. F., Sklar, L. A., Arterburn, J. B., and Prossnitz, E. R. (2005). A transmembrane intracellular estrogen receptor mediates rapid cell signaling. Science 307, 1625-1630. doi: 10.1126/science.1106943

Ritter, D. M., Ho, C., O'Leary, M. E., and Covarrubias, M. (2012). Modulation of Kv3.4 channel N-type inactivation by protein kinase $\mathrm{C}$ shapes the action potential in dorsal root ganglion neurons. J. Physiol. 590, 145-161. doi: 10.1113/ jphysiol.2011.218560

Rubio-Gayosso, I., Sierra-Ramirez, A., García-Vazquez, A., Martinez-Martinez, A., Muñoz-García, O., Morato, T., et al. (2000). 17 $\beta$-estradiol increases intracellular calcium concentration through a short-term and nongenomic mechanism in rat vascular endothelium in culture. J. Cardiovasc. Pharmacol. 36, 196-202. doi: 10.1097/00005344-200008000-00009

Shen, B., Wang, Y., Wang, X., Du, Y., Guo, S., and Cong, L. (2016). Estrogen induced the expression of ADAM9 through estrogen receptor alpha but not estrogen receptor beta in cultured human neuronal cells. Gene 576, 823-827. doi: 10.1016/j.gene.2015.11.014

Shughrue, P. J., Lane, M. V., and Merchenthaler, I. (1997). Comparative distribution of estrogen receptor $\alpha$ and $-\beta$ mRNA in the rat central nervous system. J. Comp. Neurol. 388, 507-525. doi: 10.1002/(SICI)10969861(19971201)388:4<507::AID-CNE1>3.0.CO;2-6

Shughrue, P. J., Scrimo, P. J., and Merchenthaler, I. (2000). Estrogen binding and estrogen receptor characterization $(\mathrm{ER} \alpha$ and $\mathrm{ER} \beta)$ in the cholinergic neurons of the rat basal forebrain. Neuroscience 96, 41-49. doi: 10.1016/S0306-4522(99) 00520-5

Smith, F. L., Gabra, B. H., Smith, P. A., Redwood, M. C., and Dewey, W. L. (2007). Determination of the role of conventional, novel and atypical PKC isoforms in the expression of morphine tolerance in mice. Pain 127, 129-139. doi: 10.1016/j.pain.2006.08.009

Sugawara, T., Hisatsune, C., Miyamoto, H., Ogawa, N., and Mikoshiba, K. (2017). Regulation of spinogenesis in mature Purkinje cells via mGluR/PKC-mediated phosphorylation of CaMKIIbeta. Proc. Natl. Acad. Sci. U.S.A. 114, E5256E5265. doi: 10.1073/pnas.1617270114

Summers, K. C., Bogard, A. S., and Tavalin, S. J. (2019). Preferential generation of $\mathrm{Ca}(2+)$-permeable AMPA receptors by AKAP79-anchored protein kinase C proceeds via GluA1 subunit phosphorylation at Ser-831. J. Biol. Chem. 294, 5521-5535. doi: 10.1074/jbc.RA118.004340

Takanami, K., Sakamoto, H., Matsuda, K., Hosokawa, K., Nishi, M., Prossnitz, E. R., et al. (2010). Expression of G protein-coupled receptor 30 in the spinal somatosensory system. Brain Res. 1310, 17-28. doi: 10.1016/j.brainres.2009. 11.004

Vaidya, B., Sifat, A. E., Karamyan, V. T., and Abbruscato, T. J. (2018). The neuroprotective role of the brain opioid system in stroke injury. Drug Discov. Today 23, 1385-1395. doi: 10.1016/j.drudis.2018.02.011

Wayman, G. A., Lee, Y. S., Tokumitsu, H., Silva, A. J., and Soderling, T. R. (2008). Calmodulin-kinases: modulators of neuronal development and plasticity. Neuron 59, 914-931. doi: 10.1016/j.neuron.2008.08.021

Woolley, C. S. (1999). Effects of Estrogen in the CNS. Curr. Opin. Neurobiol. 9, 349-354. doi: 10.1016/S0959-4388(99)80051-8

Wu, T. W., Chen, S., and Brinton, R. D. (2011). Membrane estrogen receptors mediate calcium signaling and MAP kinase activation in individual hippocampal neurons. Brain Res. 1379, 34-43. doi: 10.1016/j.brainres.2011.01.034

Wu, T. W., Wang, J. M., Chen, S., and Brinton, R. D. (2005). 17Beta-estradiol induced $\mathrm{Ca} 2+$ influx via L-type calcium channels activates the Src/ERK/cyclicAMP response element binding protein signal pathway and BCL-2 expression in rat hippocampal neurons: a potential initiation mechanism for estrogeninduced neuroprotection. Neuroscience 135, 59-72. doi: 10.1016/j.neuroscience. 2004.12.027

Yakel, J. L. (1997). Calcineurin regulation of synaptic function: from ion channels to transmitter release and gene transcription. Trends. Pharmacol. Sci. 18, 124-134. doi: 10.1016/S0165-6147(97)01046-8

Zeitz, K. P., Malmberg, A. B., Gilbert, H., and Basbaum, A. I. (2001). Reduced development of tolerance to the analgesic effects of morphine and clonidine in PKC? mutant mice. Pain 102, 245-253. doi: 10.1016/S0304-3959(01)00353-0

Zhao, L., Chen, S., Wang, J. M., and Briton, R. D. (2005). 17 $\beta$-estradiol induces $\mathrm{Ca}(2)+$ influx, dendritic and nuclear $\mathrm{Ca}(2)+$ rise and subsequent cyclic AMP response element-binding protein activation in hippocampal neurons: a potential initiation mechanism for estrogen neurotrophism. Neuroscience 132, 299-311. doi: 10.1016/j.neuroscience.2004.11.054

Zheng, H., Chu, J., Zhang, Y., Loh, H. H., and Law, P. Y. (2011). Modulating micro-opioid receptor phosphorylation switches agonist-dependent signaling as reflected in PKCepsilon activation and dendritic spine stability. J. Biol. Chem. 286, 12724-12733. doi: 10.1074/jbc.M110.177089

Conflict of Interest: The authors declare that the research was conducted in the absence of any commercial or financial relationships that could be construed as a potential conflict of interest.

Copyright (c) 2019 Ding, Gao, Gao, Meng, Zheng, Dong, Luo, Zhang, Shi and Rong. This is an open-access article distributed under the terms of the Creative Commons Attribution License (CC BY). The use, distribution or reproduction in other forums is permitted, provided the original author(s) and the copyright owner(s) are credited and that the original publication in this journal is cited, in accordance with accepted academic practice. No use, distribution or reproduction is permitted which does not comply with these terms. 